\title{
Protected Cultivation of Horticultural Crops in Uttarakhand: An Economic Analysis
}

\author{
Pramod Kumar ${ }^{1}$, Amit Kar ${ }^{1}$, Dharam Raj Singh ${ }^{1}{ }^{(0}$, Anbukkani Perumal ${ }^{1}$, \\ Satish Gowda Chirathahalli Shivamurthy ${ }^{2}$, Krishna Viswanatha Reddy ${ }^{3, * \mathbb{D}}$, Prakash Singh Badal ${ }^{4}$, \\ Ankush Lala Kamble ${ }^{5}$, Virendra Kamalvanshi ${ }^{4}{ }^{D}$, Girish Kumar Jha ${ }^{1}$, Manjeet Singh Nain ${ }^{1}$, \\ Prakash Pachiyappan ${ }^{6}$, Abed Alataway ${ }^{7}$, Ahmed Dewidar ${ }^{7}$ and Hosam O. Elansary ${ }^{8,9,10, *(1)}$
}

\section{check for} updates

Citation: Kumar, P.; Kar, A.; Singh, D.R.; Perumal, A.; Shivamurthy, S.G.C.; Reddy, K.V.; Badal, P.S.; Lala Kamble, A.;

Kamalvanshi, V.; Jha, G.K.; et al.

Protected Cultivation of Horticultural Crops in Uttarakhand: An Economic Analysis. Agronomy 2021, 11, 692. https://doi.org/10.3390/ agronomy 11040692

Academic Editor: Rosa Maria Fanelli

Received: 7 March 2021

Accepted: 26 March 2021

Published: 5 April 2021

Publisher's Note: MDPI stays neutra with regard to jurisdictional claims in published maps and institutional affiliations.

Copyright: (c) 2021 by the authors. Licensee MDPI, Basel, Switzerland. This article is an open access article distributed under the terms and conditions of the Creative Commons Attribution (CC BY) license (https:// creativecommons.org/licenses/by/ $4.0 /)$.
1 ICAR-Indian Agricultural Research Institute, New Delhi 110012, India; pramod.iari@gmail.com (P.K.); amitkar123@yahoo.com (A.K.); drsingh_1960@yahoo.com (D.R.S.); anbueconomic@gmail.com (A.P.); girish.stat@gmail.com (G.K.J.); msnain@gmail.com (M.S.N.)

2 ICAR-National Institute of Veterinary Epidemiology and Disease Informatics, Bangalore 560064, India; cssg86@gmail.com

3 ICAR-Central Tobacco Research Institute, Rajahmundry 533105, India

4 Banaras Hindu University, Varanasi 221005, India; badalps@gmail.com (P.S.B.); vkvanshi@bhu.ac.in (V.K.)

5 ICAR-Central Institute of Fishries Education, Mumbai 400061, India; ankush9385@gmail.com

ICAR-Central Tuber Crop Research Institute, Trivandrum 695017, India; prakashiari@yahoo.com

7 Prince Sultan Bin Abdulaziz International Prize for Water Chair, Prince Sultan Institute for Environmental, Water and Desert Research, King Saud University, Riyadh 11451, Saudi Arabia; aalataway@ksu.edu.sa (A.A.); adewidar@ksu.edu.sa (A.D.)

8 Plant Production Department, College of Food and Agriculture Sciences, King Saud University, Riyadh 11451, Saudi Arabia

9 Floriculture, Ornamental Horticulture, and Garden Design Department, Faculty of Agriculture (El-Shatby), Alexandria University, Alexandria 21545, Egypt

10 Department of Geography, Environmental Management, and Energy Studies, University of Johannesburg, APK Campus, Johannesburg 2006, South Africa

* Correspondence: vishu.uas@gmail.com (K.V.R.); helansary@ksu.edu.sa (H.O.E.)

Abstract: In recent times, with the globalization of markets, shrinking of land and climate change, food basket diversification, increase in demand for nutrient-rich food, the protected cultivation of high-value crops (HVCs) have assumed a pivotal role in augmenting higher crop productivity and profitability and enhancing nutritional security of the growing population. In this context, a study was undertaken to analyze the impact of protected cultivation in horticultural crops in the districts of Almora and Dehradun in the Uttarakhand state. It was mainly based on primary data obtained through a primary survey and focus group discussion with the 96 farmers practicing protected cultivation by using a well-structured and pre-tested questionnaire. In economic analysis, the project analysis tools were used to assess the feasibility of the protected cultivation. The study clearly demonstrated that the cultivation of vegetables and flowers under protected cultivation is a highly profitable enterprise. However, the findings of the study indicated that the subsidy scheme needs to be continued to encourage maximum farmers to adopt protected cultivation and farmers need to be encouraged to form farmers producers organizations (FPOs), which would help them in seeking better quality of inputs and enhancing negotiating power in the market to realize maximum returns for their farm produce.

Keywords: high value crops; protected cultivation; subsidy; nutrient-rich food; Uttarakhand; profitability

\section{Introduction}

Indian agriculture is constrained by shrinking land resources, growing population, increasing urbanization and industrialization, leading to changing food demand patterns. The Government of India has initiated a number of schemes and programs like e-Mandi 
(scheme to digitally link markets), soil health card, national horticulture mission, per drop more crop, Paramparagat Krishi Vikash Yojana (intended towards promoting organic farming), PMKISAN (Pradhan Mantri Kisan Sammann Nidhi -Supporting farmers through income support of Rs 6000/- per year), PMFBY (Prime Minster Fasal Bheema Yojana- an insurance service for farmers for their yields), digitization of land records, etc. [1]. These schemes are intended towards meeting SDG (Sustainable Development Goals) by way of enhancing sustainability, mitigating risk and uncertainty, bringing more transparency and efficiency in governance in rural development in general and farmers' welfare in particular. The agriculture and horticulture sectors are climate-sensitive, although hills and mountainous regions offer a great opportunity for farmers to cultivate off-season vegetables and a variety of flowers. However, growing vegetables in open conditions is subject to vagaries of weather and attack of diseases and insect pests, which could be mitigated largely through protected cultivation. With the globalization of markets, shrinking land and climate change, the protected cultivation of high-value crops has emerged as one of the most important technologies for ensuring high productivity, improved technology and profitability. Uttarakhand is primarily a mountainous state with only about $10 \%$ of its total geographical area in plains and more than three-fourth $(78 \%)$ of its total population dependent on agriculture for its livelihood. The yield from the field crops is not very high in the hilly areas of the state. The productivity of vegetable crops is unable to reach its optimum level. Low productivity may be attributed to poor infrastructure, poor irrigation, small and fragmented land holdings, low investment capacity of the farmers, fragile ecosystem and inaccessibility of technology. The migration of farmers is another major issue plaguing the farming sector. Landholdings in Uttarakhand are typically small (0.68 ha) and segmented. Uttarakhand is most vulnerable to climate-mediated risks.

The net increase in temperature of the state has ranged from $1.70{ }^{\circ} \mathrm{C}$ to $2.20^{\circ} \mathrm{C}$ and rainfall from $5 \%$ to $13 \%$ with respect to the 1970 s [2]. Some of the reported climate-changeinduced changes in the Uttarakhand Himalayas include receding glaciers and changes in snowline, depleting erratic rainfall, irregular winter rains, rise in temperature, increasing intensity and frequency of flash floods, drying up of perennial streams, etc. Promotion of protected cultivation of vegetables and flowers augers very well for the mountainous state like Uttarakhand to mitigate climate-mediated risks and also to enhance the productivity of crops. The protected cultivation of vegetables leads to higher yields, ranging from $40 \%$ to $955 \%$ as compared to open cultivation (Appendix A). A number of schemes have been implemented by the state in cooperation with the center, like the State Horticulture Mission Scheme, Schemes of National Horticulture Board, etc., to promote protected cultivation in the state. ICAR (Indian Council of Agricultrual Research) institutes like Vivekanand Institute of Parvatiya Krishi AnusandhanSansthan (VIPKAS), Almora, have specially trained the farmers in their adopted villages to erect low-cost wooden-based polyhouses and to raise vegetable crops [3]. Similarly, in Dehradun district of Uttarakhand, the farmers received the NHB (National Horticulture Board) fund support to construct polyhouses and to cultivate flower crops, especially Gerbera. However, small and marginal farmers still do not appreciate such efforts, and they are still largely deprived of their benefits $[4,5]$. It is important to understand the feasibility of polyhouse cultivation of vegetables and flowers as the other factors hindering the growth and adoption of protected cultivation. Therefore, the study was undertaken in the Uttarakhand state of India with the following specific objectives:

(a) To analyze the growth performance of the protected cultivation in Uttarakhand;

(b) To evaluate the feasibility of the protected cultivation of vegetables and flowers and implication of climate change on the same; an

(c) To assess the constraints faced by the farmers and implementing agencies in upscaling technology of protected cultivation in the state of Uttarakhand. 


\section{Materials and Methods}

The study pertains to the Almora and Dehradun districts of Uttarakhand, which represent diverse regions based on physiography. Almora district has steep mountains, while Dehradun is located in Doon Valley. In Almora, terrace farming is practiced, wherein smaller polyhouses are successful, while in Dehradun, which has plain lands, larger polyhouses are more common. The source of irrigation in Almora is by way of development of water resourcesfrom harvesting runoff and perennial hill streams in Low-Density Poly Ethylene (LDPE)-lined water tanks [6], while in Dehradun, the source of irrigation is groundwater [3]. The proximity to the Delhi market makes the Dehradun polyhouses to cultivate flowers while Almora being away from such major markets cultivation of vegetables is more common.

The study is based on both secondary and primary data. The secondary data were compiled from diverse sources. The data on physical and financial progress of various governments schemeto promote horticulture in general and the protected cultivation in particular were compiled from the Horticulture Mission for Northeast and Himalayan states and National Horticulture Mission, published by the Department of Agriculture and Cooperation, Ministry of Agriculture and Farmers Welfare, Government of India. A multilevel stratified sampling was used to collect the primary data. Two blocks of the Almora district and two blocks of Dehradun district of Uttarakhand were selected based on higher adoption of protected cultivation. In subsequent stratification, eight villages from four blocks were selected randomly. The primary data were collected from sample farmers by the personal interview method using a pre-tested structured schedule. These farmers were interviewed to collect the information on adoption pattern of protected cultivation, cost involved in crop production and the return from the crop under protected cultivation. The respondents were selected from the villages based on proportion to the population. Thus, 96 protected cultivation farmers were interviewed. This protected cultivation data wereanalyzed through simple descriptive statistics and project analysis tools, namely benefit-cost ratio, net present value and internal rate of return were computed to assess the feasibility of the protected cultivation.

The protected cultivation involves huge investment and the returns spread over a number of years. The investment decision of farmers is guided by cumulative returns from the life of the protected structure. Therefore, the project evaluation techniques, namely benefit-cost ratio (BC ratio), net present value (NPV) and internal rate of return (IRR), were employed to assess the feasibility of the protected cultivation. The formulas of the project evaluation techniques used are $[7,8]$ :

$$
\begin{gathered}
N P V=\sum_{j=1}^{n} \frac{B}{(1+r)^{n}}-\sum_{j=1}^{n} \frac{C}{(1+r)^{n}} \\
B: C \text { ratio }=\frac{\left(\sum_{j=1}^{n} \frac{B}{(1+r)^{n}}\right)}{\sum_{j=1}^{n} \frac{C}{(1+r)^{n}}} \\
I R R=\sum_{j=1}^{n} \frac{B}{(1+i)^{n}}-\sum_{j=1}^{n} \frac{C}{(1+i)^{n}}=0
\end{gathered}
$$

where, $B$ is benefit stream from protected cultivation, $C$ is cost stream which comprises of fixed cost and operational cost involved in protected cultivation, $r$ is discount rates for bringing benefit and cost stream to present level for comparison, $i$ is that discount rate at which benefit stream is equal to cost stream and it gives the IRR, $n$ is total life of the protected cultivation structure, $j$ is life of protected cultivation in years, which ranges from 1 to $n$.

The fixed cost remains the same for different crop combinations practiced by farmers. The crop sequence adopted by farmers in a year is considered to be one unit for the purpose of assessment of operational costs and returns. 
The project life of the flower-based polyhouses of Dehradun district was assumed to be of 20 years, while that of the vegetable production in low-cost polyhouses of Almora district was assumed to be 15 years. The life of polysheets was assumed to be five years and was replaced in the sixth year. In the case of gerbera cultivation, it was found that most of the farmers planted the crop once and continuedto reap the harvest for four years, and the production was highest during the first two years, after which it fell by $10 \%$. The study also internalized the effect of climate change on protected cultivation of vegetables and flowers. It was assumed that the major climatic factor influencing the polyhouse was the occurrence of strong wind, which damages the polysheets of the polyhouses. It was assumed that such events occur once in ten years, and the first event happens to be on the third year of the project life, which demands additional investment to replace the polyhouse, and there is also a reduction in the production by half of the usual production. The farmers perceptions were also recorded on constraints in the adoption and marketing of vegetables and flowers produced under protected cultivation.

\section{Results}

\subsection{Status of Horticulture in Uttarakhand}

In Uttarakhand, the area under fruits, vegetables and flowers is 1.75 lakh ha, 0.89 lakh ha and 0.02 lakh ha respectively in 2015-2016 (Table 1). The productivity of fruit is $3.76 \mathrm{t} / \mathrm{ha}$, which is $26.34 \%$ of the national average. Similarly, the productivity of vegetables is $10.52 \mathrm{t} / \mathrm{ha}$, which is $62.9 \%$ of the national average. The production of fruits has recorded marginal improvement over a period of 16 years, while that of vegetables has almost remained the same [9-11]. Thus, it is observed that there is great scope to enhance the production of horticultural crops and one of the ways is to go for protected cultivation. District-wise area and production of fruits, vegetables and flowers in Uttarakhand are displayed in Table 2. The total area under vegetables and fruits in Uttarakhand has remained almost the same at 2.39 lakh hectare.

The area under vegetables is 0.64 lakh ha while that under fruits was 1.75lakh ha accounting for $73.27 \%$ and $26.73 \%$ of the total area under fruits and vegetables. The fruits and vegetables together account for just $4.6 \%$ of the total geographical area of the state. The Almora and Dehradun districts account for $6.94 \%$ and $15.12 \%$ of the total area under vegetables while they account for $13.78 \%$ and $15.1 \%$ of the total area under fruits.

Table 1. Area and production of horticultural crops in Uttarakhand.

\begin{tabular}{|c|c|c|c|c|c|c|c|c|c|}
\hline & \multicolumn{3}{|c|}{ Fruits } & \multicolumn{3}{|c|}{ Vegetables } & \multicolumn{3}{|c|}{ Flowers } \\
\hline & $\begin{array}{c}\text { Area } \\
\left({ }^{\prime} 000 \text { ha }\right)\end{array}$ & $\begin{array}{c}\text { Production } \\
\left({ }^{\prime} 000 t\right)\end{array}$ & $\begin{array}{l}\text { Productivity } \\
\text { (t/ha) }\end{array}$ & $\begin{array}{c}\text { Area } \\
\left({ }^{\prime} 000 \text { ha }\right)\end{array}$ & $\begin{array}{l}\text { Production } \\
\quad\left({ }^{\prime} 000 \mathrm{t}\right)\end{array}$ & $\begin{array}{l}\text { Productivity } \\
\text { (t/ha) }\end{array}$ & $\begin{array}{c}\text { Area } \\
\left({ }^{\prime} 000 \mathrm{ha}\right)\end{array}$ & $\begin{array}{l}\text { Production } \\
\text { Loose } \\
\text { ('000t) }\end{array}$ & $\begin{array}{l}\text { Production } \\
\text { Cut } \\
\text { (Lakh no) }\end{array}$ \\
\hline \multicolumn{10}{|c|}{ Uttarakhand } \\
\hline 1991-1992 & $150.5(5.2)$ & $428.7(1.5)$ & $2.8(28.0)$ & $57.1(1.02)$ & $617.6(1.06)$ & 10.8 (102.9) & & & \\
\hline 2001-2002 & $197.5(4.9)$ & $376.1(0.87)$ & $1.9(17.75)$ & $93.8(1.52)$ & $737.3(0.83)$ & $7.9(54.8)$ & & & \\
\hline 2011-2012 & $200.7(2.99)$ & $802.1(1.04)$ & $4.0(35.09)$ & $89.3(0.99)$ & $1066.7(0.68)$ & $11.9(68.4)$ & $1.5(0.59)$ & $1.81(0.11)$ & $3567.6(4.75)$ \\
\hline 2015-2016 & $175.33(2.79)$ & $659.1(0.73)$ & $3.76(26.3)$ & $89.84(0.89)$ & $945.36(0.56)$ & $10.52(62.9)$ & $1.5(0.54)$ & $1.75(0.11)$ & $13.52 *(2.56)$ \\
\hline \multicolumn{10}{|c|}{ India } \\
\hline 1991-1992 & 2874.5 & 28,632 & 10 & 5592.4 & $58,520.9$ & 10.5 & & & \\
\hline 2001-2002 & 4010.2 & $43,000.9$ & 10.7 & 6155.6 & $88,620.3$ & 14.4 & & & \\
\hline 2011-2012 & 6704.2 & $76,424.2$ & 11.4 & 8989.6 & $156,325.5$ & 17.4 & 253.6 & 1650.87 & $75,066.0$ \\
\hline $2015-2016$ & 6300.67 & $90,183.04$ & 14.3 & $10,106.29$ & $169,063.93$ & 16.7 & 277.57 & 1656.24 & 527.67 \\
\hline
\end{tabular}

* indicates production of cut flowers in tons. Source: [9-11]. 
Table 2. District-wise area and production of fruits, vegetables, and flowers in Uttarakhand, 2015-2016.

\begin{tabular}{|c|c|c|c|c|c|c|c|c|c|}
\hline \multirow[t]{2}{*}{ District } & \multicolumn{3}{|c|}{ Fruits } & \multicolumn{3}{|c|}{ Vegetables } & \multicolumn{3}{|c|}{ Flowers } \\
\hline & $\begin{array}{c}\text { Area } \\
\text { ('000 ha) }\end{array}$ & $\begin{array}{l}\text { Production } \\
\text { ('000 tons) }\end{array}$ & $\begin{array}{c}\text { Yield } \\
\left.\text { (tonsha }^{-1}\right)\end{array}$ & $\begin{array}{c}\text { Area } \\
\text { (‘000 ha) }\end{array}$ & $\begin{array}{c}\text { Production } \\
\text { ('000 tons) }\end{array}$ & $\begin{array}{c}\text { Yield } \\
\left.\text { (tonsha }^{-1}\right)\end{array}$ & $\begin{array}{c}\text { Area } \\
\text { ('000 ha) }\end{array}$ & $\begin{array}{l}\text { Production } \\
\text { ('000 tons) }\end{array}$ & $\begin{array}{c}\text { Yield } \\
\left.\text { (tonsha }^{-1}\right)\end{array}$ \\
\hline Nanital & 10.83 & 109.39 & 10.1 & 5.88 & 59.70 & 10.16 & 0.06 & 0.34 & 200.07 \\
\hline Udhamsinghnagar & 7.56 & 53.14 & 7.03 & 7.44 & 89.99 & 12.1 & 0.10 & 0.18 & 54.86 \\
\hline Almora & 24.16 & 175.65 & 7.27 & 4.44 & 43.51 & 9.81 & 0.02 & 0.05 & 6.84 \\
\hline Bageswar & 3.54 & 12.63 & 3.57 & 1.58 & 8.23 & 5.22 & 0.01 & 0.00 & 3.7 \\
\hline Pithoragarh & 15.72 & 46.03 & 2.93 & 5.36 & 72.34 & 13.5 & 0.00 & 0.00 & 6.32 \\
\hline Champawat & 8.18 & 13.47 & 1.65 & 3.10 & 20.97 & 6.77 & 0.01 & 0.01 & 1.6 \\
\hline Dehradun & 26.41 & 40.06 & 1.52 & 9.67 & 70.76 & 7.32 & 0.19 & 0.10 & 506.32 \\
\hline Paudi & 20.78 & 33.33 & 1.6 & 4.77 & 34.51 & 7.23 & 0.04 & 0.01 & 103 \\
\hline Tihri & 20.94 & 28.51 & 1.36 & 8.22 & 73.89 & 8.99 & 0.01 & 0.00 & 83.96 \\
\hline Chamoli & 3.63 & 15.21 & 4.19 & 2.04 & 12.22 & 5.99 & 0.04 & 0.00 & 10.63 \\
\hline Rudraprayag & 3.11 & 2.37 & 0.76 & 1.01 & 3.09 & 3.07 & 0.06 & 0.00 & 61.5 \\
\hline Uttarkashi & 15.13 & 30.63 & 2.02 & 6.30 & 37.37 & 5.93 & 0.02 & 0.00 & 0.06 \\
\hline Haridwar & 15.34 & 98.68 & 6.43 & 4.16 & 60.55 & 14.56 & 0.77 & 0.77 & 709.45 \\
\hline Total & 175.33 & 659.09 & 3.76 & 63.95 & 587.12 & 9.18 & 1.34 & 1.47 & 1748.31 \\
\hline
\end{tabular}

Source: [12].

\subsection{Programs and Policies for Promotion of Protected Cultivation}

The Horticulture Mission for North East and Himalayan states (HMNEH)is a major program under which the funds have been allocated for the purpose of development of horticulture sector in the state of Uttarakhand [13]. The amount of funds allocated for the state increased from Rs 988 lakhs in TE 2005-2006 to Rs 3366 lakhs by the year TE 2015-2016 are given Table 3 . The fund allotted under the HMNEH program has grown at an annual growth rate of $11 \%$ during 2003-2004 to 2015-2016. Similarly, the share of funds utilized by state government decreased at the rate of $-0.3 \%$ per annum. The point of concern is the low level of fund utilization by the state which ranges from $45.0 \%$ to $72.5 \%$. Efforts need to be made to utilize maximum of available funds in order to have a larger impact.

Table 3. Funds allocated under the Horticulture Mission for North East and Himalayan states (HMNEH) program, Uttarakhand.

\begin{tabular}{ccccc}
\hline Year (TE) & $\begin{array}{c}\text { Funds Allocated in } \\
\text { Lakhs (Rs.) }\end{array}$ & $\begin{array}{c}\text { Funds Available in } \\
\text { Lakhs (Rs.) }\end{array}$ & Amount in Lakhs (Rs.) & \% to Funds Utilized \\
\cline { 4 - 5 } & 988.3 & 955.3 & 692.4 & 72.5 \\
TE 2005-2006 & 3213.3 & 4286 & 2532.8 & 59 \\
TE 2008-2009 & 2990 & 4596 & 2069.5 & 45 \\
TE 2015-2012 & 3366.7 & 4639.2 & 3200.4 & 68.9 \\
CAGR (2003-2016) & 11 & 18.2 & 17.8 & -0.3 \\
\hline
\end{tabular}

Source: [14]. Rs-Rupees, CAGR=Compound annual growth rate; TE = Triennium ending.

The state has made significant progress in the horticulture sector with the use of the funds under the HMNEH program. There are 107 nurseries that have been established in the state. An area of 75.78 ha is brought under greenhouse cultivation and 4.97 ha under shade net. To improve the transportation of fruits and vegetables from remote and inaccessible areas, 31 ropeways have been established (Table 4).

The scheme promotes the development of the horticulture sector by providing fund support in the form of subsidies. The scheme provides a $50 \%$ subsidy for the setting up of protected cultivation structures. The cost norms vary for various size of polyhouse structures and by type of structures. The fund support for protected cultivation of fruits and vegetables under fan and pad polyhouse is up to 32.2 lakh, and that under tubular structures is up to 19.41 lakhs. 
Table 4. Physical progress under HMNEH program, Uttarakhand, 2015-16.

\begin{tabular}{cc}
\hline Nurseries Set Up & $\mathbf{1 0 7}$ \\
\hline Frea expansion under Horticultural crops & 65,282 ha \\
Fruits & 34,483 ha $(52.8 \%)$ \\
Spices & 21,340 ha $(32.7 \%)$ \\
Flowers & 7369 ha $(11.3 \%)$ \\
Rejuvenation of old and senile orchards & 2090 ha (3.2\%) \\
Organic farming & 13,880 ha \\
INM/IPM area & 2970 ha \\
Water harvesting tanks/ponds (No) & 1928 ha \\
Tube wells/bore wells (No) & 1060 \\
Protected cultivation & 2440 \\
Greenhouse & \\
Shade net house & 75.78 ha \\
Anti hail nets & 4.97 ha \\
Mulching & 194.93 ha \\
Farm handling/packhouses (No) & 0.35 ha \\
Wholesale markets (No) & 1111 \\
Ropeways (No) & 3 \\
Mechanization- distribution of machines (No) & 31 \\
\hline
\end{tabular}
Source: [15].

The number of beneficiaries covered under the HMNEH programhas been very low, at just 36 and 51 for the years of 2014-2015 and 2015-2016, as given in Table 5. The average amount of subsidy disbursed was Rs 3.44 lakh and 2.28 lakhs during the years 2014-2015 and 2015-2016. This also reveals that the program's ability to promote small polyhouses may be due to paucity of funds and also due to the nature of the topography of the state. This is also obvious from the fact that in recent years i.e., 2015-2016, the majority of the polyhouses were size $200 \mathrm{~m}^{2}$ in size (Figure 1).

Table 5. Performance of HMNEH program.

\begin{tabular}{cccccc}
\hline Year & $\begin{array}{c}\text { No of } \\
\text { Beneficiaries }\end{array}$ & $\begin{array}{c}\text { Area Covered } \\
\left(\mathbf{m}^{\mathbf{2}}\right)\end{array}$ & $\begin{array}{c}\text { Subsidy Disbursed } \\
(\mathbf{R s} \text { lakh) }\end{array}$ & $\begin{array}{c}\text { Average Area } \\
\text { Covered }\left(\mathbf{m}^{\mathbf{2}}\right)\end{array}$ & $\begin{array}{c}\text { Average Subsidy } \\
\text { Disbursed }(\mathbf{R s} \mathbf{l a k h})\end{array}$ \\
\hline $2014-2015$ & 36 & 25,000 & 123.89 & 694.5 & 3.44 \\
$2015-2016$ & 51 & 22,390 & 116.16 & 439.02 & 2.28 \\
\hline
\end{tabular}

Source: [16].

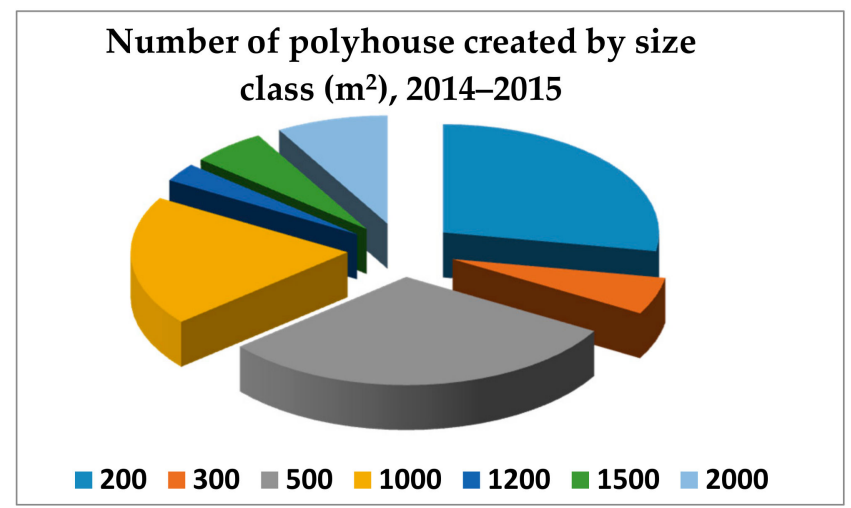

(a)

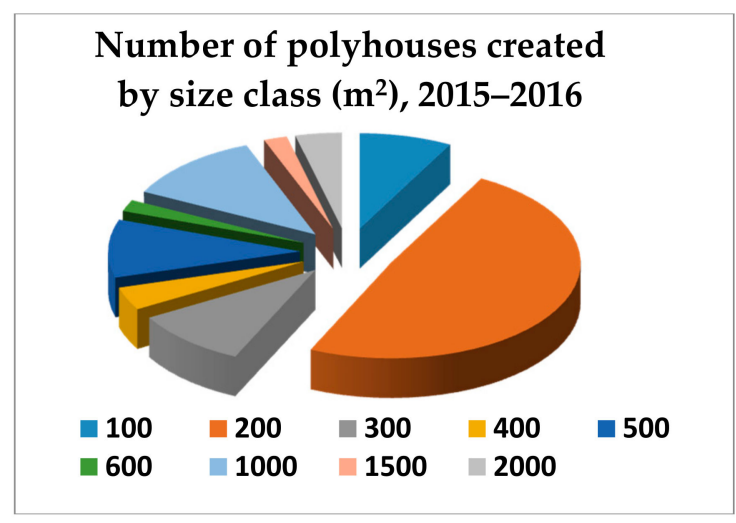

(b)

Figure 1. Number of polyhouses created during 2014-2015 (a) and 2015-2016 (b). 


\subsection{Performance of Mission for Integrated Development of Horticulture (MIDH)}

The Mission for Integrated Development of Horticulture (MIDH) scheme provides assistance for the promotion of horticulture in general and protected cultivation in particular. The program supports large sizes of polyhouse units. The fund support for greenhouse structure ranges from Rs 5.63 lakhs to Rs 20.13 lakhs, depending upon the nature of polyhouse and also on the size of the polyhouse. The scheme also provides support in the form of $50 \%$ subsidy for purchase of planting material. The MIDH scheme fund flows through the National Horticulture Board. The scheme took off very well in the state with 124 beneficiaries receiving support in the year 2010-2011; however, the scheme slowed down in its performance. The revealed slackness in performance could be due to cost escalation of the polyhouses due to which only a few beneficiaries could be supported with the given amount of scheme fund. The performance of the NHB scheme in Uttarakhand is displayed in Table 6.

Table 6. Performance of National Horticulture Board scheme in Uttarakhand.

\begin{tabular}{ccccc}
\hline Year & $\begin{array}{c}\text { No of } \\
\text { Beneficiaries }\end{array}$ & $\begin{array}{c}\text { Project Cost } \\
\text { (in Rs lakh) }\end{array}$ & $\begin{array}{c}\text { Amount } \\
\text { Released } \\
\text { (in Rs lakh) }\end{array}$ & $\begin{array}{c}\text { Amount Released } \\
\text { Per Beneficiary } \\
\text { (Rs lakh) }\end{array}$ \\
\hline $2010-2011$ & 124 & 1469.49 & 299.12 & 2.41 \\
$2011-2012$ & 65 & $11,050.88$ & 327.86 & 5.04 \\
$2012-2013$ & 26 & 660.08 & 130.44 & 5.01 \\
$2013-2014$ & 41 & 1376.11 & 363.03 & 8.85 \\
$2014-2015$ & 14 & 647.71 & 128.10 & 9.15 \\
$2015-2016$ & 33 & 1542.73 & 622.46 & 18.86 \\
Total & 303 & $16,747.00$ & 1871.01 & 6.17 \\
\hline Source: [17]. & & & &
\end{tabular}

\subsection{Economics of Protected Cultivation}

This section presents the results of analysis of the field data pertaining to the general information of the farmers practicing protected cultivation in Almora and Dehradun districts of Uttarakhand. Out of the surveyed sample of 36, 18 farmers i.e., $50 \%$ of the farmers who adopted protected cultivation technique are more than 45 years of age (Table 7). Only $11 \%$ of the farmers are less than 30years of age. The remaining $39 \%$ of the farmers are between 30years and 45 years of age. On the basis of caste, it can be seen that $89 \%$ of the farmer belong to the general category, only $11 \%$ are Other Backward Classesand none of the farmers belong to the schedule caste or scheduled tribe. Education plays an important role in the adoption of modern technology. However, out of the sample surveyed, $50 \%$ of the farmers only passed high school. Lack of knowledge and education also affects the production of the crop. Only $22 \%$ of the farmers are either graduates or postgraduates. Thus, they have better knowledge and understanding of using the new and advanced technology. Of the sample of 18 farmers surveyed, $44 \%$ of the farmers belong to Bhagertala village in Almora district, and 33\% belong to Todra village. Farmers belonging to Dudoli and Shahi Devi villages formed a small portion. Only four farmers out of 36 have more than five polyhouses, i.e., just $11 \%$, and 16 farmers have less than 2 polyhouses or between 2 and 5 polyhouses.

Having experience in a particular field adds to productivity. Three-fifths of the farmers have 4 to 8 of experience years in protected cultivation. Eleven percentof farmers have more than 8 years of experience, and $27.7 \%$ of the farmers have less than 4 years of experience. The total population of Almora district was 1.35 lakh as per the 2001 census. The majority of the population surveyed is engaged in agriculture. Only $11 \%$ of the total surveyed are engaged in business/service. 
Table 7. Classification of farmers based on various socio-economic characteristics $(\mathrm{N}=96)$.

\begin{tabular}{|c|c|c|c|c|c|}
\hline \multirow[b]{2}{*}{ Socio-Economic Features } & \multirow[b]{2}{*}{ Classification } & \multicolumn{2}{|c|}{ Almora Farmers } & \multicolumn{2}{|c|}{ Dehradun Farmers } \\
\hline & & $\begin{array}{c}\text { Number of } \\
\text { Farmers }\end{array}$ & \%age $(\%)$ & $\begin{array}{c}\text { Number of } \\
\text { Farmers }\end{array}$ & $\%$ age $(\%)$ \\
\hline \multirow{3}{*}{ Age (Years) } & $0-30$ & 4 & 11.1 & 8 & 13 \\
\hline & $30-45$ & 14 & 38.9 & 30 & 50 \\
\hline & More than 45 & 18 & 50 & 22 & 37 \\
\hline \multirow{3}{*}{ Caste } & General & 32 & 88.89 & 40 & 66.7 \\
\hline & OBC & 4 & 11.11 & 20 & 33.3 \\
\hline & $\mathrm{SC} / \mathrm{ST}$ & 0 & 0 & 0 & 0 \\
\hline \multirow{3}{*}{ Education } & Intermediate & 10 & 27.78 & 10 & 16.7 \\
\hline & High & 18 & 50 & 35 & 58.3 \\
\hline & Graduation \& Above & 8 & 22.22 & 15 & 25 \\
\hline \multirow{3}{*}{$\begin{array}{l}\text { Ownership of polyhouses } \\
\qquad(\mathrm{No})\end{array}$} & Less than 2 & 16 & 44.44 & 28 & 46.7 \\
\hline & 2 to 5 & 16 & 44.44 & 22 & 36.7 \\
\hline & More than 5 & 4 & 11.12 & 10 & 16.7 \\
\hline \multirow{3}{*}{ Experience (Years) } & Less than 4 & 10 & 27.78 & 25 & 41.7 \\
\hline & 4 to 8 & 22 & 61.11 & 33 & 55 \\
\hline & More than 8 & 4 & 11.11 & 2 & 3.3 \\
\hline \multirow{2}{*}{ Occupation } & Agriculture & 32 & 88.89 & 27 & 45 \\
\hline & Business/service & 4 & 11.11 & 33 & 55 \\
\hline
\end{tabular}

OBC—Other Backward Class, SC—Scheduled Castes and ST—Schedule Tribes.Source: Authors calculations based on field survey (2017).

\subsection{Establishment Cost of Polyhouse in Uttarakhand}

The types of polyhouses prevalent in the two districts of Uttarakhand are different. In Almora district, the smaller polyhouses are popular, while in Dehradun, larger polyhouses are popular. The nature of crops taken also varied with the cultivators of Almora district cultivated vegetables under polyhouse, while in Dehradun it was the flowers and mainly the Gerbera. The establishment cost of smaller $\left(100 \mathrm{~m}^{2}\right)$ polyhouses as practiced in Almora district under wooden-based and GI (Galvonised Iron)-framed structures is presented in Table 8. The wooden-based structure is much cheaper and works out to Rs 71,000 . The highest proportion of this cost is accounted for by angle iron, which accounts for $26.5 \%$ (Rs.18000) of the total establishment cost. While the irrigation structure cost constitutes about $21.16 \%$, polysheet constitutes $21.12 \%$ of the total establishment cost. Other costs like wooden poles, land preparation, water tank sheet, labour and nutbolt constitute $10.36 \%, 7.11 \%, 7.04 \%, 5.66 \%$, and $0.96 \%$ of the total establishment cost, respectively. Own contribution is $71.83 \%$ (Rs.51000) of the total cost. The polythese sheets were provided by VIPKAS and thereby amount for a net subsidy of Rs 20,000.

Further, Table 8 shows that about $40 \%$ of the sample farmers of the Almora district had adopted GI frame polyhouses, which were funded under the HMNEM scheme. The scheme provides an $80 \%$ subsidy to the farmers, and the remaining $20 \%$ of the cost of the polyhouses is contributed by the farmers. The average cost of the polyhouse with a tank is Rs 141,900/-. The farmers' investment is Rs 52,900/-, and the rest is provided by the state government (Rs 28,050/-) and the HMNEM scheme (Rs 60950/-). The cost of establishment of polyhouse in Dehradun district of Uttarakhand has also been computed and is presented in Table 9. The polyhouses were classified into four categories based on the area of polyhouses, i.e., $1000 \mathrm{~m}^{2}, 2000 \mathrm{~m}^{2}, 4000 \mathrm{~m}^{2}$ and $1000 \mathrm{~m}^{2}$. The fixed cost of construction of the polyhouses is Rs 10.13 lakhs, Rs 19.70 lakhs, Rs 38.5 lakhs and Rs 95.57 lakhs for the polyhouses of the sizes $1000 \mathrm{~m}^{2}, 2000 \mathrm{~m}^{2}, 4000 \mathrm{~m}^{2}$ and $10,000 \mathrm{~m}^{2}$, respectively. The polyhouses used different levels of technology. The smaller size polyhouses were naturally ventilation-based polyhouses. These lacked investment for artificially managing the temperature and humidity. 
Table 8. Cost of establishment of Polyhouse in Almora district of Uttarakhand.

\begin{tabular}{|c|c|c|}
\hline \multirow{2}{*}{ Particulars } & \multicolumn{2}{|c|}{ Cost of Construction of Polyhouse (Rs/100 $\left.\mathrm{m}^{2}\right)$} \\
\hline & Amount (Rs) & Share in Total Cost $(\%)$ \\
\hline $\begin{array}{l}\text { (A) Wooden pole polyhouse } \\
\text { (VIPKS promoted) }\end{array}$ & & \\
\hline (i) Land preparation & 5056 & 7.1 \\
\hline (ii) Irrigation structure & 15,028 & 21.2 \\
\hline (iii) Water tank sheet & 5000 & 7.0 \\
\hline (iv) Polysheet & 15,000 & 21.1 \\
\hline (v) Angle & 18,861 & 26.6 \\
\hline (vi) Nutbolt & 686 & 1.0 \\
\hline (vii) Wooden pole & 736 & 10.4 \\
\hline (viii) Labour & 4022 & 5.7 \\
\hline Total cost & 71,014 & 100.0 \\
\hline Own contribution & 51,014 & 71.8 \\
\hline VIPKAS (polythene) & 20,000 & 28.2 \\
\hline Total cost & 71,014 & 100 \\
\hline $\begin{array}{l}\text { (B) Angle iron/GI pipe polyhouse } \\
\text { (a) Construction of polyhouse (funded } \\
\text { under CM sanrakshitKhetiprogram) }\end{array}$ & & \\
\hline (i) HMNEH contribution & 60,950 & 42.9 \\
\hline (ii) State government contrition & 28,050 & 19.8 \\
\hline (iii) Farmer contribution & 32,900 & 23.2 \\
\hline (b) Construction of tank & & \\
\hline (i) Digging of tank & 15,000 & 10.6 \\
\hline (ii) Polythene cover & 5000 & 3.5 \\
\hline Total cost & 141,900 & 100 \\
\hline
\end{tabular}

Source: Authors calculations based on field survey, 2017.

Table 9. Cost of establishment of Polyhouse in Dehradun district of Uttarakhand (Rs).

\begin{tabular}{ccccc}
\hline Particulars & $\mathbf{1 0 0 0} \mathbf{~ m}^{\mathbf{2}}$ & $\mathbf{2 0 0 0} \mathbf{~ m}^{\mathbf{2}}$ & $\mathbf{4 0 0 0} \mathbf{~}^{\mathbf{2}}$ & $\mathbf{1 0 , 0 0 0} \mathbf{~ m}^{\mathbf{2}}$ \\
\hline Cost of polyhouse & 907,200 & $1,800,000$ & $3,600,000$ & $8,750,000$ \\
Sprayers & 5000 & 5000 & - & 12,000 \\
Generators & - & - & - & 67,500 \\
Coolers & - & - & - & 25,000 \\
Fencing & - & - & - & 87,500 \\
Electricity line & 15,000 & 15,000 & 15,000 & 15,000 \\
Foggers & - & - & - & 15,000 \\
Tullupump & - & - & - & 10,000 \\
Drip irrigation & 50,400 & 100,000 & 200,000 & 500,000 \\
Bore well motor & 35,000 & 50,000 & 35,000 & 75,000 \\
Total Fixed Cost & $1,012,600$ & $1,970,000$ & $3,850,000$ & $9,557,000$ \\
\hline
\end{tabular}

Source: Authors calculations based on field survey, 2017.

\subsection{Cost of Cultivation of Crops under Protected Cultivation}

The farmers of Almora district were cultivating the vegetables in small polyhouses. A diverse array of vegetables were taken up by the farmers, important among them being nine different types of vegetables namely, tomato, both early and long duration; cucumber; cauliflower; cabbage; capsicum; green pea; brinjal; and potato. The costs and returns of these major vegetables are illustrated in Table 10. 
Table 10. Cost of cultivation of major vegetable crops cultivated under polyhouse in Almora district of Uttarakhand (size $100 \mathrm{~m}^{2}$; Amount in Rs).

\begin{tabular}{|c|c|c|c|c|c|c|c|c|c|}
\hline Particulars & $\begin{array}{l}\text { Long Duration } \\
\text { Tomato }\end{array}$ & $\begin{array}{c}\text { Short Duration } \\
\text { Tomato }\end{array}$ & Cucumber & Cauliflower & Cabbage & Capsicum & Green Pea & Brinjal & Potato \\
\hline Labour CostField preparation & 833.3 & 833.3 & 908.3 & 1175.0 & 1154.2 & 1175.0 & 758.3 & 758.3 & 1050.0 \\
\hline Sowing & 516.7 & 516.7 & 525.0 & 516.7 & 516.7 & 516.7 & 420.8 & 575.0 & 875.0 \\
\hline Fertilizer and manure & 108.3 & 108.3 & 104.2 & 116.7 & 116.7 & 116.7 & 116.7 & 116.7 & 116.7 \\
\hline Weeding (women) & 511.1 & 511.1 & 533.3 & 475.0 & 475.0 & 600.0 & 455.2 & 455.2 & 463.9 \\
\hline PPC & 100.0 & 100.0 & 116.7 & 116.7 & 116.7 & 116.7 & 116.7 & 116.7 & 116.7 \\
\hline Irrigation & 600.0 & 525.0 & 395.8 & 412.5 & 412.5 & 779.2 & 575.0 & 575.0 & 583.3 \\
\hline Harvesting cost (female) & 833.3 & 700.0 & 594.4 & 344.4 & 365.6 & 558.3 & 558.3 & 558.3 & 498.0 \\
\hline Total female labour (man days) & 6.7 & 6.1 & 5.6 & 4.1 & 4.2 & 5.8 & 5.1 & 5.1 & 5.1 \\
\hline Male Labour charges & 2158.3 & 2083.3 & 1654.2 & 1925.0 & 1904.2 & 1925.0 & 1412.5 & 1566.7 & 2158.3 \\
\hline Female Labour charges & 1344.4 & 1211.1 & 1127.8 & 819.4 & 840.6 & 1158.3 & 1013.6 & 1013.6 & 1022.2 \\
\hline total labour charges & 3502.8 & 3294.4 & 2781.9 & 2744.4 & 2744.7 & 3083.3 & 2426.1 & 2580.2 & 3180.6 \\
\hline Input costSeeds & 719.4 & 719.4 & 195.6 & 486.1 & 479.2 & 554.2 & 554.2 & 554.2 & 495.8 \\
\hline FYM & 861.1 & 750 & 850.0 & 650.0 & 0.0 & 625.0 & 550.0 & 686.1 & 725.0 \\
\hline NPK & 250.0 & 175 & 250.0 & 388.9 & 381.9 & 415.3 & 415.3 & 415.3 & 415.3 \\
\hline PPC & 447.2 & 350 & 228.9 & 311.1 & 298.6 & 346.1 & 346.1 & 546.1 & 625.3 \\
\hline Stacking \& Pinching & 750.0 & 650 & 1000.0 & 0.0 & 0.0 & 0.0 & 436.1 & 0.0 & 0.0 \\
\hline Total cost & 8397 & 7484 & 7134 & 5572 & 4929 & 6016 & 5719 & 5774 & 6434 \\
\hline Production & 737.5 & 515 & 1041.7 & 366.7 & 424.4 & 409.7 & 250.0 & 374.7 & 891.7 \\
\hline Average Price & 31.6 & 31.6 & 20.0 & 32.2 & 20.0 & 32.2 & 40.0 & 40.0 & 20.0 \\
\hline Gross Return & 22,125 & 16,274 & 20,833 & 11,000 & 8489 & 12,292 & 10,000 & 14,989 & 17,833 \\
\hline Net Return & 13,803 & 8790 & 14,624 & 6078 & 3559 & 6901 & 4831 & 9215 & 11,461 \\
\hline
\end{tabular}

Source: Authors calculations based on field survey, 2017. 
The farmers cultivated mainly nine different types of vegetables in the polyhouses. The cost and returns of each of these crops are presented in Table 10. The cost incurred in raising these crops ranges from Rs 4929/- for cabbage to Rs 8397/- for tomato. The variable cost involved in cultivation of the vegetable crops is one of the important considerations for choice of the crops. It is observed that the net return ranges from Rs. 3559/- for cabbage to Rs 14624/- for cucumber. One of the major advantages of polyhouse cultivation of vegetables is that it is gender-neutral and even the femalesgets equal opportunity to work and manage the cultivation.

Further, the table sheds light on the average production and returns from the cultivation of tomato under protected cultivation. The total cost of cultivation of tomato only under protected cultivation was Rs.8397. The average production was 738 quintals. The average price realized in the market was Rs.32 per $\mathrm{kg}$. As revealed from the table, a net return of Rs.13,803 per $100 \mathrm{~m}^{2}$ was realized from the cultivation of tomato.

The farmers cultivated a combination of crops under polyhouse based on resources, convenience and training. The majority of the farmers raised tomato and tomato-based cropping sequences. Tomato gave regular income on every alternate day, and there is well-developed marketing channel by which the harvest reaches the market. However, a few farmers did cultivate diversified crops on a $100 \mathrm{~m}^{2}$ area generally to overcome market risk and to meet the home requirement of vegetables. This is revealed from Table 11, that the combination of three crops, namely brinjal-pea-potato, gives higher net returns per year of Rs. 25,507 and was followed by that from tomato-pea-potato, which resulted in a net return of Rs.25,082. Thus it is revealed that the farmers should cultivate more crops in a crop sequence to realize a higher return. Of course, this would involve a higher investment to meet out the variable cost of cultivation of more number of crops. If a farmer has four such playhouses then they can get a net return of Rs 102,028/-, which is more than sufficient to sustain a family in the villages of the mountainous district of Almora. It would also generate 128 man-days of productive employment. Thus promotionof polyhouse could be one of the solutions for preventing migrationand also doubling the farmers income [4].

Table 11. The cropping pattern practiced under polyhouse cultivation in Almora district of Uttarakhand.

\begin{tabular}{cc}
\hline Cropping Pattern & Net Return Per Year (Rs) \\
\hline Tomato (Pacheti) & 13,803 \\
Capsicum-Pea & 11,732 \\
Capsicum-Tomato & 15,691 \\
Cucumber-Pea & 19,455 \\
Cucumber-Tomato & 23,414 \\
Tomato-Pea & 13,621 \\
Tomato-Pea-Potato & 25,082 \\
Tomato-Cabbage & 12,349 \\
Brinjal-Pea-Potato & 25,507 \\
Cucumber-cauliflower & 20,702 \\
\hline
\end{tabular}

Source: Authors calculations based on field survey, 2017.

The costs of cultivation of gerbera under polyhouse in Dehradun district of Uttarakhand are displayed in Table 12. The polyhouses were classified based on the area of polyhouses, i.e., $1000 \mathrm{~m}^{2}, 2000 \mathrm{~m}^{2}, 4000 \mathrm{~m}^{2}, 10,000 \mathrm{~m}^{2}$. The total cost of cultivation of gerbera under polyhouseswasRs. 3.42 lakhs, 5.98 lakhs, 13.22 lakhs, 33.57 lakhs for the polyhouses sizes of $1000 \mathrm{~m}^{2}, 2000 \mathrm{~m}^{2}, 4000 \mathrm{~m}^{2}, 10,000 \mathrm{~m}^{2}$. The cost of bulbs forms the major cost, forming $60 \%$ to $65 \%$ of the total variable cost. The other major cost is the land preparation, application of farm yard manure (FYM), use of plant protection chemicals(PPC), packaging and transport of produce. The gerbera crop involves a huge investment in first year and remains in field for four years and it involves only maintenance cost. 
Table 12. Cost of cultivation of gerbera for different size category of the polyhouses in Dehradun district of Uttarakhand (Rs).

\begin{tabular}{|c|c|c|c|c|c|c|c|c|}
\hline \multirow[b]{2}{*}{ Particulars } & \multicolumn{2}{|c|}{$1000 \mathrm{~m}^{2}$} & \multicolumn{2}{|c|}{$2000 \mathrm{~m}^{2}$} & \multicolumn{2}{|c|}{$4000 \mathrm{~m}^{2}$} & \multicolumn{2}{|c|}{$10,000 \mathrm{~m}^{2}$} \\
\hline & $\begin{array}{l}\text { Amount } \\
\text { (Rs) }\end{array}$ & $\begin{array}{l}\% \text { to } \\
\text { Total }\end{array}$ & $\begin{array}{l}\text { Amount } \\
\text { (Rs) }\end{array}$ & $\begin{array}{l}\% \text { to } \\
\text { Total }\end{array}$ & $\begin{array}{l}\text { Amount } \\
\quad(\mathrm{Rs})\end{array}$ & $\begin{array}{l}\% \text { to } \\
\text { Total }\end{array}$ & $\begin{array}{l}\text { Amount } \\
\text { (Rs) }\end{array}$ & $\begin{array}{l}\% \text { to } \\
\text { Total }\end{array}$ \\
\hline Bulb & 211,680 & 61.8 & 360,000 & 60.2 & 840,000 & 63.5 & $2,187,500$ & 65.1 \\
\hline Bulb labour & 500 & 0.1 & 833 & 0.1 & 16,000 & 1.2 & 6833.3 & 0.2 \\
\hline Land preparation & 10,080 & 2.9 & 20,000 & 3.3 & 40,000 & 3.0 & 100,000 & 3.0 \\
\hline Sowing & 6720 & 2.0 & 13,333 & 2.2 & $26,666.7$ & 2.0 & $66,666.7$ & 2.0 \\
\hline Farm Yard Manure (FYM) & 8571.4 & 2.5 & 16,667 & 2.8 & $88,524.6$ & 6.7 & 100,000 & 3.0 \\
\hline FYM Labour & 300 & 0.1 & 933 & 0.2 & 6300 & 0.5 & 4666.7 & 0.1 \\
\hline Rice Husk & 2857.1 & 0.8 & 8000 & 1.3 & 9263.2 & 0.7 & $28,666.7$ & 0.9 \\
\hline Rice Husk labour & 300 & 0.1 & 800 & 0.1 & 583.3 & 0.0 & 4666.7 & 0.1 \\
\hline Neem khali & 2857.1 & 0.8 & 3333 & 0.6 & 10,000 & 0.8 & 10,000 & 0.3 \\
\hline Inter-culture & 3000 & 0.9 & 6250 & 1.0 & $15,789.5$ & 1.2 & 28,000 & 0.8 \\
\hline Fertiliser & 7056 & 2.1 & 28,000 & 4.7 & $29,473.7$ & 2.2 & 105,000 & 3.1 \\
\hline $\begin{array}{l}\text { Plant protection chemicals } \\
\text { (PPC) }\end{array}$ & 25,000 & 7.3 & 20,000 & 3.3 & 36,000 & 2.7 & 73,000 & 2.2 \\
\hline PPC labour & 1200 & 0.4 & 2500 & 0.4 & 2800 & 0.2 & 7500 & 0.2 \\
\hline Irrigation labour & 1200 & 0.4 & 3600 & 0.6 & 14,000 & 1.1 & 10,850 & 0.3 \\
\hline Irrigation electricity & 10,000 & 2.9 & 12,000 & 2.0 & 18,000 & 1.4 & 21,000 & 0.6 \\
\hline Harvesting & 2400 & 0.7 & 5000 & 0.8 & 10,500 & 0.8 & 36,000 & 1.1 \\
\hline Packaging & 12,600 & 3.7 & 25,000 & 4.2 & 45,000 & 3.4 & 190,000 & 5.7 \\
\hline Transport & 30,240 & 8.8 & 60,000 & 10.0 & 100,000 & 7.6 & 330,000 & 9.8 \\
\hline Rent & 6000 & 1.8 & 12,000 & 2.0 & $13,333.3$ & 1.0 & 47,500 & 1.4 \\
\hline Total Variable Cost & $342,561.7$ & & 598,250 & & $1,322,234$ & & $3,357,850$ & \\
\hline
\end{tabular}

Source: Authors' calculations based on field survey, 2017

\subsection{Feasibility of Protected Cultivation in Uttarakhand}

The feasibility of the protected cultivation of vegetables in Almora under the woodbased and GI frame polyhouses and the feasibility of protected cultivation of flowers in Dehradun has been systematically evaluated. For this purpose, the project analysis tools were employed to estimate the B:C ratio (benefit-cost ratio), NPV (Net Present Value) and IRR (Internal Rate of Return) under three sets of scenarios viz.,

(a) With and without subsidy;

(b) Under three sets ofdiscount i.e., 5\%, 7.5\% and 10\%, which are comparable to the prevailing rate of interest for short term and term loans for agriculture from financial institutions [18,19]; and

(c) Different combinations of vegetable crops.

In cases without the subsidy for setting up of wood-based polyhouses and with discount rate of $5 \%$, the IRR was found to range from $9.5 \%$ (capsicum-pea) to $32.6 \%$ (brinjal-pea-potato), depending on the crops raised by the farmers. The NPV ranged from Rs 22,135 to Rs 165,114/- 9.5\%and B:C ratio ranged from 1.22 to 2.66. Thus, on all three project analysis measures the protected cultivation of vegetables under the wood-based polyhouse is observed to be feasible.However, under the higher discount rate scenario, the feasibility is affected. This means that if one is not receiving any subsidy it is advisable to resort to low rate of fund raising for setting up of wood based polyhouse and to continue with the cultivation. Under the scenario with a subsidy along with a $5 \%$ discount rate, the wood-based protected cultivation of vegetables in Almora district is observed to be very profitable, with the IRR ranging from 16\% (capsicum-pea) to $46.5 \%$ (brinjal-peapotato). The NPV ranged from Rs 42,135/- to Rs 185,114/- and B:C ratio from 1.53 to 3.32 (Table 13). Thus, by all three evaluation measures, the protected cultivation of vegetables under wood-based polyhouse is found to highly rewarding as the farmers receive the subsidy for setting up the polyhouse. The evaluation of protected cultivation of vegetables in Almora district with subsidy and at higher discount rate also the values of NPV, B:C ratio do not fall much and reveal the profitability of vegetable cultivation. 
Table 13. Feasibility analysis of protected cultivation of vegetables under wood-based polyhouse in Almora district of Uttarakhand.

\begin{tabular}{|c|c|c|c|c|c|c|c|}
\hline \multirow{2}{*}{ Crop Combination } & \multirow{2}{*}{ Feasibility Criteria } & \multicolumn{3}{|c|}{ without Subsidy } & \multicolumn{3}{|c|}{ with Subsidy } \\
\hline & & $5 \%$ & $7.50 \%$ & $10 \%$ & $5 \%$ & $7.50 \%$ & $10 \%$ \\
\hline \multirow{3}{*}{ Tomato } & NPV (Rs) & 43,632 & 27,048 & 14,002 & 63,632 & 47,048 & 34,002 \\
\hline & $\mathrm{B}: \mathrm{C}$ ratio & 1.44 & 1.29 & 1.15 & 1.80 & 1.63 & 1.48 \\
\hline & IRR (\%) & 13.5 & & & 21.2 & & \\
\hline \multirow{3}{*}{ Capsicum-pea } & NPV (Rs) & 22,135 & 8767 & -1751 & 42,135 & 28,767 & 18,249 \\
\hline & $\mathrm{B}: \mathrm{C}$ ratio & 1.22 & 1.09 & 0.98 & 1.53 & 1.38 & 1.26 \\
\hline & IRR & 9.5 & & & 16 & & \\
\hline \multirow{3}{*}{ Capsicum-tomato } & NPV (Rs) & 63,233 & 43,718 & 28,365 & 83,233 & 63,718 & 48,365 \\
\hline & $\mathrm{B}: \mathrm{C}$ ratio & 1.63 & 1.46 & 1.31 & 2.05 & 1.85 & 1.68 \\
\hline & IRR & 16.9 & & & 25.6 & & \\
\hline \multirow{3}{*}{ Cucumber-pea } & NPV (Rs) & 96,589 & 72,084 & 52,808 & 116,589 & 92,084 & 72,808 \\
\hline & $\mathrm{B}: \mathrm{C}$ ratio & 1.97 & 1.76 & 1.58 & 2.46 & 2.23 & 2.03 \\
\hline & IRR & 22 & & & 32.6 & & \\
\hline \multirow{3}{*}{ Cucumber-tomato } & NPV (Rs) & 143,396 & 111,890 & 87,107 & 163,396 & 131,890 & 107,107 \\
\hline & $\mathrm{B}: \mathrm{C}$ ratio & 2.44 & 2.18 & 1.96 & 3.05 & 2.76 & 2.51 \\
\hline & IRR & 29 & & & 42 & & \\
\hline \multirow{3}{*}{ Tomato-pea } & NPV (Rs) & 41,742 & 25,441 & 12,617 & 61,742 & 45,441 & 32,617 \\
\hline & $\mathrm{B}: \mathrm{C}$ ratio & 1.42 & 1.27 & 1.14 & 1.78 & 1.61 & 1.46 \\
\hline & IRR & 13.2 & & & 20.8 & & \\
\hline \multirow{3}{*}{ Tomato-pea-potato } & NPV (Rs) & 160,701 & 126,607 & 99,788 & 180,701 & 146,607 & 119,788 \\
\hline & $\mathrm{B}: \mathrm{C}$ ratio & 2.61 & 2.34 & 2.10 & 3.27 & 2.96 & 2.69 \\
\hline & IRR & 31.9 & & & 45.6 & & \\
\hline \multirow{3}{*}{ Tomato-cabbage } & NPV (Rs) & 28,547 & 14,220 & 2948 & 48,547 & 34,220 & 22,948 \\
\hline & $\mathrm{B}: \mathrm{C}$ ratio & 1.29 & 1.15 & 1.03 & 1.61 & 1.46 & 1.32 \\
\hline & IRR & 10.8 & & & 17.8 & & \\
\hline \multirow{3}{*}{ Brinjal-pea-potato } & NPV (Rs) & 165,114 & 130,360 & 103,022 & 185,114 & 150,360 & 123,022 \\
\hline & $\mathrm{B}: \mathrm{C}$ ratio & 2.66 & 2.38 & 2.13 & 3.32 & 3.01 & 2.73 \\
\hline & IRR & 32.6 & & & 46.5 & & \\
\hline \multirow{3}{*}{ Cucumber-cauliflower } & NPV (Rs) & 115,243 & 87,948 & 66,478 & 135,243 & 107,948 & 86,478 \\
\hline & $\mathrm{B}: \mathrm{C}$ ratio & 2.16 & 1.93 & 1.73 & 2.70 & 2.44 & 2.22 \\
\hline & IRR & 25.2 & & & 36.5 & & \\
\hline
\end{tabular}

Source: Authors calculations based on field survey, 2017.

The evaluation of GI frame polyhouses for cultivation of vegetables in Almoradisctrict without subsidy at a lower discount rate of $5 \%$ reveals that very few crop combinations appear to be rewarding. Thus the farmer, has to be very enterprising and always on toe to be able to sustain himself. The profitability of vegetable cultivation deteriorates drastically with an increase in discount rate to $7.5 \%$ and $10 \%$. However, the situation under the with subsidy and at $5 \%$ discount rate the IRR ranges from 15.5 to 44.7 , the $\mathrm{B}: \mathrm{C}$ ratio ranges from 1.45 to 3.25 and the NPV ranges from Rs 40,249/- to Rs 183,229/-. Thus, it is revealed that it is quite rewarding to cultivate vegetables under GI frame polyhouse setup with the help of subsidy.

Thus, it can be stated that the farmers should adopt multiple cropsin order tomaximize their returns. Secondly, provisioning of the subsidy would encourage more farmers to adopt polyhouse cultivation of vegetables in the hilly terrain of Uttarakhand (Table 14). Any public sector institution has limitations in granting subsidies on a long-term basis. It is therefore desired that the state government should further take up this initiative and help in the promotion of polyhouse cultivation of vegetables in the district of Almora with technical help from ICAR-VIPKAS. It was observed that in the sample region, only $20 \%$ of the farmers had adopted the state-government-promoted polyhouse. The state 
government should take this initiative on a mass scale looking at the profitability and sustenance demonstrated by the ICAR-VIPKAS promoted polyhouses.

Table 14. Feasibility analysis of protected cultivation of vegetables under GI frame polyhouse in Almora district of Uttarakhand.

\begin{tabular}{|c|c|c|c|c|c|c|c|}
\hline \multirow{2}{*}{ Crop Combination } & \multirow{2}{*}{ Feasibility Criteria } & \multicolumn{3}{|c|}{ without Subsidy } & \multicolumn{3}{|c|}{ with Subsidy } \\
\hline & & $5 \%$ & $7.50 \%$ & $10 \%$ & $5 \%$ & $7.50 \%$ & $10 \%$ \\
\hline \multirow{3}{*}{ Tomato } & NPV (Rs) & $-27,254$ & $-43,838$ & $-56,884$ & 61,746 & 45,162 & 32,116 \\
\hline & $\mathrm{B}: \mathrm{C}$ ratio & 0.84 & 0.74 & 0.65 & 1.76 & 1.59 & 1.44 \\
\hline & IRR (\%) & 1.9 & & 20.3 & & & \\
\hline \multirow{3}{*}{ Capsicum-pea } & NPV (Rs) & $-48,751$ & $-62,119$ & $-72,637$ & 40,249 & 26,881 & 16,363 \\
\hline & $\mathrm{B}: \mathrm{C}$ ratio & 0.71 & 0.63 & 0.55 & 1.49 & 1.35 & 1.22 \\
\hline & IRR & $-1 \%$ & & & 15.5 & & \\
\hline \multirow{3}{*}{ Capsicum-tomato } & NPV (Rs) & -7653 & $-27,168$ & $-42,521$ & 81,347 & 61,832 & 46,479 \\
\hline & $\mathrm{B}: \mathrm{C}$ ratio & 0.96 & 0.84 & 0.74 & 2.00 & 1.81 & 1.64 \\
\hline & IRR & 4.2 & & & 24.5 & & \\
\hline \multirow{3}{*}{ Cucumber-pea } & NPV (Rs) & 25,703 & 1198 & $-18,078$ & 114,703 & 90,198 & 70,922 \\
\hline & $\mathrm{B}: \mathrm{C}$ ratio & 1.15 & 1.01 & 0.89 & 2.41 & 2.18 & 1.97 \\
\hline & IRR & 7.6 & & & 31.4 & & \\
\hline \multirow{3}{*}{ Cucumber-tomato } & NPV (Rs) & 72,510 & 41,004 & 16,221 & 161,510 & 130,004 & 105,221 \\
\hline & $\mathrm{B}: \mathrm{C}$ ratio & 1.43 & 1.25 & 1.10 & 2.98 & 2.70 & 2.44 \\
\hline & IRR & 12 & & & 40.5 & & \\
\hline \multirow{3}{*}{ Tomato-pea } & NPV (Rs) & $-29,144$ & $-45,445$ & $-58,269$ & 59,856 & 43,555 & 30,731 \\
\hline & $\mathrm{B}: \mathrm{C}$ ratio & 0.83 & 0.73 & 0.64 & 1.73 & 1.57 & 1.42 \\
\hline & IRR & 1.70 & & & 19.9 & & \\
\hline \multirow{3}{*}{ Tomato-pea-potato } & NPV (Rs) & 89,815 & 55,721 & 28,902 & 178,815 & 144,721 & 117,902 \\
\hline & $\mathrm{B}: \mathrm{C}$ ratio & 1.53 & 1.34 & 1.18 & 3.19 & 2.89 & 2.62 \\
\hline & IRR & 13.50 & & & 43.90 & & \\
\hline \multirow{3}{*}{ Tomato-cabbage } & NPV (Rs) & $-42,339$ & $-56,666$ & $-67,938$ & 46,661 & 32,334 & 21,062 \\
\hline & $\mathrm{B}: \mathrm{C}$ ratio & 0.75 & 0.66 & 0.58 & 1.57 & 1.42 & 1.29 \\
\hline & IRR & 0 & & & 17 & & \\
\hline \multirow{3}{*}{ Brinjal-pea-potato } & NPV (Rs) & 94,228 & 59,474 & 32,136 & 183,228 & 148,474 & 121,136 \\
\hline & $\mathrm{B}: \mathrm{C}$ ratio & 1.55 & 1.36 & 1.20 & 3.25 & 2.94 & 2.66 \\
\hline & IRR & 13.9 & & & 44.7 & & \\
\hline \multirow{3}{*}{$\begin{array}{l}\text { Cucumber with } \\
\text { cauliflower }\end{array}$} & NPV (Rs) & 44,357 & 17,062 & -4408 & 133,357 & 106,062 & 84,592 \\
\hline & $\mathrm{B}: \mathrm{C}$ ratio & 1.26 & 1.10 & 0.97 & 2.64 & 2.38 & 2.16 \\
\hline & IRR & 9.4 & & & 35.1 & & \\
\hline
\end{tabular}

Source: Authors calculations based on field survey, 2017.

The feasibility of polyhouse cultivation of gerbera was evaluated and is presented in Table 15. It is observed that without subsidy, the cultivation of gerbera across different sizes of polyhouse is feasible with realizable IRR ranging from $24 \%$ to $39 \%$ across the various sizes of polyhouses. The B:C ratio even at the higher discount rates of $15 \%$ is observed to range from 1.22 to 1.41 , revealing high profitability of cultivation of flowers in Dehradun under polyhouse. The IRR of gerbera cultivation with subsidy on playhouse ranges from $48 \%$ to $75 \%$, while with subsidy on polyhouse and planting material, it ranges from $57 \%$ to $99 \%$. Thus, it reveals that the protected cultivation of gerbera is a very attractive enterprise and it needs to be further promoted.It therefore reinforces the belief that the subsidy needs to be continued to further promote the adoption of polyhouse cultivation. 
Table 15. Feasibility of polyhouse cultivation of Gerbera in Dehradun district of Uttarakhand, India.

\begin{tabular}{|c|c|c|c|c|c|c|c|c|c|}
\hline & \multicolumn{4}{|c|}{ Benefit-Cost Ratio } & \multicolumn{4}{|c|}{ Net Present Value (Lakh Rs) } & \multirow{2}{*}{ IRR (\%) } \\
\hline & $5 \%$ & $7.50 \%$ & $10 \%$ & $15 \%$ & $5 \%$ & $7.50 \%$ & $10 \%$ & $15 \%$ & \\
\hline \multicolumn{10}{|c|}{ Without subsidy on polyhouses } \\
\hline $1000 \mathrm{~m}^{2}$ & 1.52 & 1.46 & 1.36 & 1.22 & 20 & 15 & 10 & 5 & 24 \\
\hline $2000 \mathrm{~m}^{2}$ & 1.76 & 1.68 & 1.56 & 1.39 & 55 & 40 & 29 & 16 & 31 \\
\hline $4000 \mathrm{~m}^{2}$ & 1.89 & 1.81 & 1.68 & 1.49 & 129 & 95 & 70 & 40 & 34 \\
\hline $10,000 \mathrm{~m}^{2}$ & 1.83 & 1.74 & 1.60 & 1.41 & 308 & 223 & 158 & 85 & 39 \\
\hline \multicolumn{10}{|c|}{ With subsidy on polyhouse } \\
\hline $1000 \mathrm{~m}^{2}$ & 1.75 & 1.69 & 1.63 & 1.52 & 24 & 19 & 15 & 9 & 48 \\
\hline $2000 \mathrm{~m}^{2}$ & 2.03 & 1.97 & 1.90 & 1.76 & 61 & 48 & 38 & 25 & 61 \\
\hline $4000 \mathrm{~m}^{2}$ & 2.37 & 2.28 & 2.20 & 2.04 & 158 & 124 & 99 & 66 & 77 \\
\hline $10,000 \mathrm{~m}^{2}$ & 2.27 & 2.19 & 2.12 & 1.97 & 384 & 301 & 240 & 159 & 75 \\
\hline \multicolumn{10}{|c|}{$\begin{array}{c}\text { With subsidy on polyhouse and } \\
\text { planting material }\end{array}$} \\
\hline $1000 \mathrm{~m}^{2}$ & 1.81 & 1.76 & 1.71 & 1.61 & 25 & 20 & 16 & 10 & 57 \\
\hline $2000 \mathrm{~m}^{2}$ & 2.10 & 2.04 & 1.98 & 1.85 & 63 & 50 & 40 & 26 & 70 \\
\hline $4000 \mathrm{~m}^{2}$ & 2.47 & 2.39 & 2.32 & 2.17 & 163 & 129 & 103 & 70 & 88 \\
\hline $10,000 \mathrm{~m}^{2}$ & 3.04 & 2.93 & 2.82 & 2.61 & 460 & 364 & 293 & 199 & 99 \\
\hline
\end{tabular}

Source: Authors calculation based on field survey, 2017.

\subsection{Feasibility of Polyhouse Cultivation under the Climate Change Scenario}

The cultivation of vegetables and flowers under polyhouses protects the crops from many of the aspects of climate change, like temperature, relative humidity, rainfall, etc. However, one such climate change event is the occurrence of storms, which damages the polyhouse structure itself. One such event had occurred in the recent past, and during the survey, it was observed that about $10 \%$ of farmers had left their polyhouses in damaged condition, where they were still practicing cultivation of vegetables. Most of the farmers had made temporary arrangements by way of repairing themselves with the help of adhesive tapes. A few farmers were lucky to have been granted with polysheets through local-level elected members. The recurrence of a storm is damaging the polyhouse structure, and this particular climatic event is quantified and has been used for simulating its impact on the feasibility of the polyhouse cultivation of vegetables and flowers. The analysis presumes that (i) storms occur once every five years, (ii) it damages the polysheets of the polyhouse and, finally, (iii) it brings down the production of vegetables and flowers to $50 \%$ of its potential in that year.

(a) Feasibility of wood-basedpolyhouses for vegetable cultivation: The vegetable cultivation under wood-based polyhouses reveals that under subsidy-based polyhouses, it remains feasible (Table 16). Thus, the farmer is better able to absorb the risk and continue with cultivation year after year. However, under the without subsidy scenario, it is observed that in very few crop combinations, the feasibility is observed and in most of the crop combinations, it is observed that the farmer suffers losses, and in many others, the return is not very attractive. It is this very reason of risk due to climatic factors that explains the behavior of the farmers to continue to look for the government subsidy to be able to adopt even such low-cost technology.

(b) Feasibility of GI frame polyhouses for vegetable cultivation: The feasibility of GI frame polyhouses for vegetable cultivation was also assessed under the situation of having faced a climatic risk (Table 17). It is observed that the number of crop combinations for which it remains feasible is further reduced, and very few crop combinations reveal feasibility. It is thus construed that it is not feasible to opt for GI-frame polyhouses for vegetable cultivation, and therefore, it calls for continuance of the subsidy to make it attractive for the farmers to adopt the technology of protected cultivation of vegetables. 
Table 16. Feasibility analysis of protected cultivation of vegetables under wood-based polyhouse in Almora district of Uttarakhand under climate change situations.

\begin{tabular}{|c|c|c|c|c|c|c|}
\hline \multirow{2}{*}{ Crop Combination } & \multicolumn{3}{|c|}{ without Subsidy } & \multicolumn{3}{|c|}{ with Subsidy } \\
\hline & $5 \%$ & $7.50 \%$ & $10 \%$ & $5 \%$ & $7.50 \%$ & $10 \%$ \\
\hline \multicolumn{7}{|l|}{ NPV (Rs) } \\
\hline Tomato & 23,710 & 9708 & -1330 & 43,710 & 29,708 & 18,670 \\
\hline Capsicum with pea & 3657 & -7336 & $-16,005$ & 23,657 & 12,664 & 3995 \\
\hline Capsicum with tomato & 41,995 & 25,248 & 12,050 & 61,995 & 45,248 & 32,050 \\
\hline Cucumber with pea & 73,111 & 51,694 & 34,821 & 93,111 & 71,694 & 54,821 \\
\hline Cucumber with tomato & 116,774 & 88,804 & 66,773 & 136,774 & 108,804 & 86,773 \\
\hline Tomato with pea & 21,947 & 8209 & -2620 & 41,947 & 28,209 & 17,380 \\
\hline Tomato pea potato & 132,917 & 102,524 & 78,586 & 152,917 & 122,524 & 98,586 \\
\hline Tomato with cabbage & 9639 & -2252 & $-11,638$ & 29,639 & 17,748 & 8372 \\
\hline Brinjal pea potato & 137,034 & 106,023 & 81,599 & 157,034 & 126,023 & 101,599 \\
\hline $\begin{array}{c}\text { Cucumber with cauliflower } \\
\text { B:C ratio }\end{array}$ & 90,512 & 66,484 & 47,555 & 110,512 & 86,484 & 67,555 \\
\hline Tomato & 1.22 & 1.09 & 0.99 & 1.49 & 1.35 & 1.24 \\
\hline Capsicum with pea & 1.03 & 0.93 & 0.84 & 1.26 & 1.15 & 1.05 \\
\hline Capsicum with tomato & 1.38 & 1.24 & 1.12 & 1.69 & 1.54 & 1.41 \\
\hline Cucumber with pea & 1.67 & 1.5 & 1.35 & 2.04 & 1.85 & 1.69 \\
\hline Cucumber with tomato & 2.06 & 1.85 & 1.67 & 2.52 & 2.3 & 2.1 \\
\hline Tomato with pea & 1.2 & 1.08 & 0.97 & 1.47 & 1.34 & 1.22 \\
\hline Tomato pea potato & 2.21 & 1.99 & 1.79 & 2.7 & 2.46 & 2.25 \\
\hline Tomato with cabbage & 1.09 & 0.98 & 0.88 & 1.33 & 1.21 & 1.11 \\
\hline Brinjal pea potato & 2.25 & 2.02 & 1.82 & 2.75 & 2.5 & 2.28 \\
\hline $\begin{array}{c}\text { Cucumber with cauliflower } \\
\text { IRR }(\%)\end{array}$ & 1.82 & 1.64 & 1.48 & 2.23 & 2.03 & 1.85 \\
\hline Tomato & 10 & & & 16 & & \\
\hline Capsicum with pea & 6 & & & 11 & & \\
\hline Capsicum with tomato & 13 & & & 20 & & \\
\hline Cucumber with pea & 18 & & & 27 & & \\
\hline Cucumber with tomato & 25 & & & 35 & & \\
\hline Tomato with Pea & 9 & & & 16 & & \\
\hline Tomato, Pea, Potato & 27 & & & 38 & & \\
\hline Tomato with Cabbage & 7 & & & 13 & & \\
\hline Brinjal pea potato & 28 & & & 39 & & \\
\hline Cucumber with cauliflower & 21 & & & 30 & & \\
\hline
\end{tabular}

(c) Feasibility of GI frame polyhouses for flower cultivation: The cultivation of gerbera with protected cultivation under larger polyhouses has been estimated (Table 18). It is observed that the protected cultivation of gerbera is sustainable and viable even with the climatic risk. The reason is that the damage caused due to the climatic risk is much less in proportion to the total investment involved in such polyhouses. However, the feasibility of polyhouse cultivation of gerbera under the without subsidy scenario doesnot seem to be very attractive and thus entails the continuance of the subsidy scheme to further promote the adoption of the protected cultivation of gerbera.

\subsection{Marketing Channel Followed by the Poly House Cultivators}

The majority of the farmers are following marketing channel I and marketing channel III (Table 19). The reason being the vegetables are harvested almost every day and so the volume of production is small which is not feasible for individual polyhouse farmers to take it to the market on their own. Thus, they harvest the produce, pack it in plastic bags and transport it through the aggregator to the local wholesaler. These two channels are longer, such that the greater the number of intermediaries the lower the producers' share in consumers' share.

The gerbera cultivators follow three types of marketing channels (Table 20). Marketing channel I involves the sale of produce in the Dehradun market itself, which is consumed 
locally. Those producers who have little volume of production or whose production cycle is in the third or fourth year followmarketing channel I. Marketing channel II is mainly followed by large-scale and professionally managed producers who directly sell their produce to the Delhi market. Marketing channel III is the most widely followed channel, especially by the new entrants in the field and those who are not able to devote more time in the farming business.Marketing channel I is followed by $10 \%$ of total producers, marketing channel II is followed by $15 \%$ of the total producer and the remaining $75 \%$ of producers follow marketing channel III. The price realization in marketing channel II is the highest, and therefore, the aim of all the producers should be to ultimately follow marketing channel II. This is possible by forming a farmer Producer Company, which would assist the farmers in seeking better-quality inputs and also help in accessing better markets for the produce.

Table 17. Feasibility analysis of protected cultivation of vegetables under GI-frame polyhouse in Almora district of Uttarakhand under climate change conditions.

\begin{tabular}{|c|c|c|c|c|c|c|}
\hline \multirow{2}{*}{ Crop Combination } & \multicolumn{3}{|c|}{ without Subsidy } & \multicolumn{3}{|c|}{ with Subsidy } \\
\hline & $5 \%$ & $7.50 \%$ & $10 \%$ & $5 \%$ & $7.50 \%$ & $10 \%$ \\
\hline \multicolumn{7}{|l|}{ NPV (Rs) } \\
\hline Tomato & $-47,176$ & $-61,178$ & $-72,216$ & 41,824 & 27,822 & 16,784 \\
\hline Capsicum with Pea & $-67,229$ & $-78,222$ & $-86,891$ & 21,771 & 10,778 & 2109 \\
\hline Capsicum with tomato & $-28,891$ & $-45,638$ & $-58,836$ & 60,109 & 43,362 & 30,164 \\
\hline Cucumber with pea & 2225 & $-19,192$ & $-36,065$ & 91,225 & 69,808 & 52,935 \\
\hline Cucumber with tomato & 45,888 & 17,918 & -4113 & 134,888 & 106,918 & 84,887 \\
\hline Tomato with pea & $-48,939$ & $-62,677$ & $-73,506$ & 40,061 & 26,323 & 15,494 \\
\hline Tomato pea potato & 62,031 & 31,638 & 7700 & 151,031 & 120,638 & 96,700 \\
\hline Tomato with cabbage & $-61,247$ & $-73,138$ & $-82,514$ & 27,753 & 15,862 & 6486 \\
\hline Brinjal pea potato & 66,148 & 35,137 & 10,713 & 155,148 & 124,137 & 99,713 \\
\hline $\begin{array}{l}\text { Cucumber with cauliflower } \\
\text { B:C ratio }\end{array}$ & 19,626 & -4402 & $-23,331$ & 108,626 & 84,598 & 65,669 \\
\hline Tomato & 0.74 & 0.65 & 0.58 & 1.46 & 1.32 & 1.21 \\
\hline Capsicum with pea & 0.63 & 0.55 & 0.49 & 1.24 & 1.13 & 1.03 \\
\hline Capsicum with tomato & 0.84 & 0.74 & 0.65 & 1.65 & 1.51 & 1.37 \\
\hline Cucumber with pea & 1.01 & 0.89 & 0.79 & 1.99 & 1.81 & 1.65 \\
\hline Cucumber with tomato & 1.25 & 1.1 & 0.98 & 2.47 & 2.25 & 2.05 \\
\hline Tomato with pea & 0.73 & 0.64 & 0.57 & 1.44 & 1.31 & 1.19 \\
\hline Tomato pea potato & 1.34 & 1.18 & 1.05 & 2.64 & 2.41 & 2.19 \\
\hline Tomato with cabbage & 0.66 & 0.58 & 0.51 & 1.3 & 1.18 & 1.08 \\
\hline Brinjal pea potato & 1.37 & 1.2 & 1.06 & 2.69 & 2.45 & 2.23 \\
\hline $\begin{array}{l}\text { Cucumber with cauliflower } \\
\text { IRR (\%) }\end{array}$ & 1.11 & 0.97 & 0.86 & 2.18 & 1.99 & 1.81 \\
\hline Tomato & -1 & & & 15 & & \\
\hline Capsicum with pea & -3 & & & 11 & & \\
\hline Capsicum with tomato & 2 & & & 19 & & \\
\hline Cucumber with pea & 5 & & & 26 & & \\
\hline Cucumber with tomato & 9 & & & 34 & & \\
\hline Tomato with pea & -1 & & & 15 & & \\
\hline Tomato pea potato & 11 & & & 37 & & \\
\hline Tomato with cabbage & -2 & & & 12 & & \\
\hline Brinjal pea potato & 11 & & & 38 & & \\
\hline Cucumber with cauliflower & 7 & & & 29 & & \\
\hline
\end{tabular}


Table 18. Feasibility of polyhouse cultivation of Gerbera under climate change conditions.

\begin{tabular}{|c|c|c|c|c|c|c|c|c|c|c|}
\hline \multirow{2}{*}{ Sl. No. } & \multirow{2}{*}{$\begin{array}{c}\text { Size of } \\
\text { Polyhouse }\end{array}$} & \multicolumn{4}{|c|}{ Benefit-Cost Ratio } & \multicolumn{4}{|c|}{ Net Present Value (Lakh Rs) } & \multirow{2}{*}{$\begin{array}{l}\text { IRR } \\
(\%)\end{array}$} \\
\hline & & $5 \%$ & $7.50 \%$ & $10 \%$ & $15 \%$ & $5 \%$ & $7.50 \%$ & $10 \%$ & $15 \%$ & \\
\hline \multicolumn{11}{|c|}{ A. Without subsidy on polyhouse } \\
\hline & $1000 \mathrm{~m}^{2}$ & 1.40 & 1.34 & 1.25 & 1.11 & 16 & 11 & 7 & 3 & 20 \\
\hline & $2000 \mathrm{~m}^{2}$ & 1.56 & 1.49 & 1.38 & 1.22 & 42 & 30 & 20 & 9 & 24 \\
\hline & $4000 \mathrm{~m}^{2}$ & 1.89 & 1.81 & 1.68 & 1.49 & 129 & 95 & 70 & 40 & 34 \\
\hline & $10,000 \mathrm{~m}^{2}$ & 1.83 & 1.74 & 1.60 & 1.41 & 308 & 223 & 158 & 85 & 31 \\
\hline \multicolumn{11}{|c|}{ B. With subsidy on polyhouse } \\
\hline & $1000 \mathrm{~m}^{2}$ & 1.55 & 1.49 & 1.43 & 1.32 & 18 & 14 & 10 & 6 & 35 \\
\hline & $2000 \mathrm{~m}^{2}$ & 1.86 & 1.79 & 1.73 & 1.60 & 53 & 41 & 32 & 20 & 51 \\
\hline & $4000 \mathrm{~m}^{2}$ & 2.16 & 2.08 & 2.00 & 1.85 & 140 & 109 & 86 & 56 & 66 \\
\hline & $10,000 \mathrm{~m}^{2}$ & 2.02 & 1.94 & 1.86 & 1.71 & 317 & 244 & 191 & 121 & 60 \\
\hline \multicolumn{11}{|c|}{ C. With subsidy on polyhouse and planting material } \\
\hline & $1000 \mathrm{~m}^{2}$ & 1.66 & 1.61 & 1.56 & 1.46 & 21 & 16 & 13 & 8 & 46 \\
\hline & $2000 \mathrm{~m}^{2}$ & 1.92 & 1.86 & 1.80 & 1.68 & 55 & 42 & 33 & 22 & 56 \\
\hline & $4000 \mathrm{~m}^{2}$ & 2.44 & 2.40 & 2.35 & 2.26 & 153 & 122 & 99 & 68 & 77 \\
\hline & $10,000 \mathrm{~m}^{2}$ & 2.93 & 2.79 & 2.66 & 2.42 & 416 & 325 & 259 & 172 & 87 \\
\hline
\end{tabular}

Source: Authors calculation based on field survey, 2017.

Table 19. Marketing channel followed by the farmers of Almora for cultivation and sale of vegetables under polyhouses.

\begin{tabular}{|c|c|c|c|c|c|}
\hline \multicolumn{6}{|c|}{ Marketing channel I } \\
\hline Producer & Aggregator & $\begin{array}{c}\text { Wholesaler at } \\
\text { Almora }\end{array}$ & & Retailer & Consumer \\
\hline \multicolumn{6}{|c|}{ Marketing channel II } \\
\hline Producer & & $\begin{array}{c}\text { Wholesaler at } \\
\text { Almora }\end{array}$ & & Retailer & Consumer \\
\hline \multicolumn{6}{|c|}{ Marketing channel III } \\
\hline Producer & Aggregator & $\begin{array}{l}\text { Wholesaler at } \\
\text { Haldwani }\end{array}$ & $\begin{array}{l}\text { Wholesaler at Delhi, } \\
\text { Lucknow etc. }\end{array}$ & Retailer & Consumer \\
\hline \multicolumn{6}{|c|}{ Marketing channel IV } \\
\hline Producer & & $\begin{array}{c}\text { Wholesaler at } \\
\text { Almora }\end{array}$ & $\begin{array}{c}\text { Wholesaler at } \\
\text { Haldwani }\end{array}$ & Retailer & Consumer \\
\hline
\end{tabular}

Arrows indicates the channels of vegetables sold by the farmers.

Table 20. Marketing channel followed by the farmers of Dehradun for cultivation and sale of Gerbera under polyhouses.

\begin{tabular}{|c|c|c|c|c|}
\hline \multicolumn{5}{|c|}{ Marketing channel I } \\
\hline Producer & & $\begin{array}{l}\text { Wholesaler } \\
\text { at Dehradun }\end{array}$ & Retailer & $\begin{array}{c}\text { Consumer at } \\
\text { Dehradun }\end{array}$ \\
\hline \multicolumn{5}{|c|}{ Marketing channel II } \\
\hline Producer & & $\begin{array}{l}\text { Wholesaler } \\
\text { at Delhi }\end{array}$ & Retailer & $\begin{array}{c}\text { Consumer at } \\
\text { Delhi }\end{array}$ \\
\hline \multicolumn{5}{|c|}{ Marketing channel III } \\
\hline Producer & Aggregator & $\begin{array}{l}\text { Wholesaler } \\
\text { at Delhi }\end{array}$ & Retailer & $\begin{array}{c}\text { Consumer at } \\
\text { Delhi }\end{array}$ \\
\hline
\end{tabular}

\subsection{Constraints and Training Needs of Polyhouse Cultivators}

(a) Constraints in Almora district for cultivation of vegetables under protected cultivation

The Garrett ranking technique was used to identify the constraints under protected cultivation. The results from Table 21 indicated that the polyhouse cultivators faced a number of constraints like non-availability of a proper market, poor price received, 
unavailability of quality inputs, lack of transportation facility and non-availability of skilled labor. It was observed during the survey that about $50 \%$ of the farmers had reported damage in polythene sheets due to the heavy storm. The poor farmers did not resort to replacement of the polysheet of the polyhouse; rather, they were managing with it by repairing the sheets. In one village, the local Member of Legislative Assembly came forward to replace the damaged polythene sheets. Therefore, it is necessary to insure the polythene sheets, for which some insurance agencies should come forward to do the same. The Almora district lacks organized mandi for vegetables. The farmers are forced to sell their produce to the local wholesalers who donot pay the right price for their produce. The lack of connectivity from villages to the road and to the market is another major challenge the farmers face. The farmers need to organize themselves in the form of selfhelp groups/farmers producer organizations in order to be able to pool their resources and produce and enhance their bargaining power.

Table 21. Constraints faced by polyhouse farmers.

\begin{tabular}{ccc}
\hline Particulars & $\begin{array}{c}\text { \% of Farmers Reported } \\
\text { the Constraints }\end{array}$ & Rank \\
\hline Non-availability of proper market & 93.33 & 1 \\
Poor price received & 91.67 & 2 \\
Non-availability of inputs & 86.67 & 3 \\
Transportation problems & 83.33 & 4 \\
Non-availability of skilled labor & 80.00 & 5 \\
Difficulty in getting subsidy & 76.67 & 6 \\
Difficulty in getting credit & 75.00 & 7 \\
Higher risk & 75.00 & 7 \\
High wages of labor & 73.33 & 8 \\
Lack of local technical expertise & 71.67 & 9 \\
Poor storage facilities & 68.33 & 10 \\
Lack of pack houses & 66.67 & 11 \\
Lack of processing facility & 58.33 & 12 \\
Lack of support from Govt./institution & 53.33 & 13 \\
High incidence of insect pest or diseases & 50.00 & 14
\end{tabular}

The polyhouse cultivation being capital and knowledge-intensive the farmers expressed a need for training in a number of areas to improve their skill and knowledge. The major areas are vegetable cultivation, agronomic practices, nursery raising, and repairs and maintenance of the structures as shown in Table 22. The funds available under the HMNEH scheme are difficult to access by the poor farmers. The scope of the scheme and quantity of funds need to be enhanced so that the benefit of the scheme can be realized by the farmers. The Krishi Vigyan Kendra (Farm Science Centre) located in the Almora district comes under the GBPUAT (GovindBallabh Pant University of Agriculture And Technology), Pantnagar, Uttarakhand. It suffers from a lack of adequate funds for undertaking training sessions and demonstrations. There is a lack of polyhouses on farms, which could be used for the training and skill enhancement of the farmers of the region. The Uttarakhand government has created Mobile Horticulture units, which are located at block level. The people have high expectations from such units for provisioning of seeds, high-quality planting material, plant protection chemicals, etc. However, the people are not satisfied with these institutions for meeting the input requirements related to protected cultivation. There is no organized mandi in the Almora for vegetables. It is the presence of a few Arathias in the town to which the villagers and commission agents bring their produce. The buyers of the vegetables from the Arathias are the local vendors who often collude with each other while the auction is going on by these Arathias. Thus, the desired price is not realized by the producers in Almora market. The vegetable produce is also taken to the Haldwani market. These Arathias in these markets have developed contact with the producers of different districts of Uttarakhand. The farmer producers of Almorato 
take the produce to Haldwani market. The Arathias provide credit for purchase of seeds, pesticide and fertilizers at the beginning of the season. They also provide credit to such producers during social functions like the marriage of children, death ceremony, festivals, etc. In this way, a long-term relationship is maintained between the producer and the Arathias. The farmers with the polyhouses developed by VIPKAS were very much satisfied with the scientific and technical advice they receive from scientists.

Table 22. Training needs of polyhouse cultivators.

\begin{tabular}{ccc}
\hline Particulars & $\begin{array}{c}\text { \% of Farmers Reported the } \\
\text { Need for Training }\end{array}$ & Rank \\
\hline Vegetable cultivation & 83.33 & 1 \\
Agronomic practices & 80.00 & 2 \\
Nursery raising & 75.00 & 3 \\
Repair and maintenance of structures & 66.67 & 4 \\
Fertigation unit & 61.67 & 5 \\
Flower cultivation & 50.00 & 6 \\
Processing & 48.33 & 7 \\
Trainings on export aspects & 45.00 & 8 \\
Packaging & 41.67 & 9 \\
\hline
\end{tabular}

Source: Authors calculations based on field survey, 2017.

They have the phone numbers of the scientists and often call them to seek advice about the control for the pest and diseases. VIPKAS has adopted these villages under the MeraGaon and Mera Gaurav, and thus their scientists frequently visit these villages and offer advisory services.

(b) Constraints in Dehradun for cultivation of Gerbera under protected cultivation

The polyhouse cultivators of gerbera expressed a number of constraints, which demands the attention of policymakers. The high incidence of pests and diseases is one of the important constraints (Table 23). Lack of technical help is another constraint. The successful cultivators were totally dependent on the private planting material suppliers, who also provided the advisory services from time to time. The Krishi VignanKendrais located in Dehradun but is unable to cater to the needs of such highly skill-oriented enterprises that are dispersed all through the district. Though a few of the cultivators did report getting technical help, it needs to be further expanded. Marketing of the produce is another major challenge; as a result, the farmers had to sell the produce to the Delhi market to get a good price. Dehradun does not have flower mandi, which forces farmers to look for other markets. The small amount of produce that is harvested almost every day is aggregated by the transporter who collects from each of the polyhouses and then takes it to the Delhi market. The small volume and distant market add to the marketing cost of the flowers. At Dehradun, the polyhouses were also seen to have been ripped off by the storm. A few had repaired them and were managing with the polyhouse. A few others had replaced the polythene sheet. The farmers desired that the insurance firms should come forward to insure the structure against natural calamities. However, it was observed that the banks in their own interest were getting those insured, which was valid for the first few years till the loan amount was recovered, after which the insurance firms were not agreeing to insure the polyhouse structure. There should be policy-level decision to force the insurance firm to insure the structures of the polyhouses if the farmer wishes to do so.

Table 24 shows that the polyhouses cultivators of gerbera also expressed a need for training and skill development on various aspects of cultivation. The most important was for agronomic practices of cultivation of various flowers and vegetables under protected cultivation. Raising nurseries of flowers and vegetables was another aspect where the farmers felt the need for training. Application of liquid fertilizer is also a skillful task and demands a thorough understanding of the right dose and quantity of fertilizer to be applied. The control of pests and diseases is also a concern: once they attack the polyhouse, they are difficult to control unless the right kind of pesticide/fungicide is applied. 
Table 23. Constraints in the adoption of polyhouse cultivation in Dehradun district of Uttaranchal.

\begin{tabular}{cc}
\hline Particulars & Rank \\
\hline High incidence of insect pest or diseases & I \\
Lack of local technical expertise & II \\
Non-availability of skilled labor & III \\
Lack of support from government institutions & IV \\
Non-availability of proper market & VI \\
High wages of labor & VII \\
Poor price received & VIII \\
Difficulty in getting credit & VIII \\
High cost of planting material & IX \\
Difficulty in getting subsidy & IX \\
Transportation problems & X \\
\hline
\end{tabular}

Source: Authors calculations based on field survey, 2017.

Table 24. Training needs of polyhouse cultivators.

\begin{tabular}{cc}
\hline Particulars & Rank \\
\hline Agronomic practices & I \\
Flower cultivation & II \\
Nursery raising & III \\
Vegetable cultivation & IV \\
Control of pest and diseases & IV \\
Fertigation unit & V \\
Repair and maintenance structure & VI \\
Export process and market identification & VII \\
Packaging & VIII \\
\hline
\end{tabular}

Source: Authors calculations based on field survey, 2017.

\subsection{Reason for Discontinuation}

About $20 \%$ of the sample polyhouses were observed to be abandoned by the cultivators. The higher risk associated with the polyhouse cultivation is one of the prime reasons for abandoning the cultivation under polyhouse (Table 25). This high risk is due to many factors. The use of poor quality of planting material emerged as the most important reason for higher risk. The cost of planting material in the case of gerbera is very high. The quality of planting material is very crucial to getting theright kind and quality of flowers. The polyhouse cultivation of gerbera demands the use of liquid fertilizer, which is again a very costly input and adds to the overall cost of cultivation of gerbera. Inadequate technical help is another major problem, which results in farmers not knowing how to control pests and diseases, leading to an increase in the cost of pesticide/fungicide used to control them. This adds to the cost and often loss of crops. The KVKs could come to the rescue of such specialized and highly knowledge-intensive enterprises. Lack of personal supervision has been another major cause for incurring loss leading to the abandonment of the polyhouse, since the businessmen/service personnel who already owned most of the previously occupied polyhouses left the polyhouses under the supervision of hired laborers/supervisors. 
Table 25. Reasons for discontinuation of protected cultivation.

\begin{tabular}{cc}
\hline Particulars & Rank \\
\hline Poor quality seeds/planting material & 1 \\
Costly seeds/planting material & 2 \\
Higher risk & 2 \\
Poor returns due to low price & 2 \\
Costly liquid fertilizer & 3 \\
Marketing problems & 3 \\
High maintenance cost & 3 \\
Inadequate technical help & 3 \\
Poor returns due to low yield & 4 \\
Nematode infestation & 5 \\
Lack of supervision & 6 \\
Poor cold chain facility & 7 \\
Lack of trainings & 7 \\
Subsidy on planting material/seed/fertilizer is not available & 7 \\
Natural calamities & 8 \\
\hline
\end{tabular}

Source: Authors calculations based on field survey, 2017.

\section{Conclusions and Policy Implications}

Uttarakhand is primarily a mountainous state, with only about $10 \%$ of its total geographical area in plains beingintended for cultivation, and the productivity of vegetables is low. In addition, the migration of farmers is a growing concern, faced with climatemediated risks. Therefore, the promotion of protected cultivation of vegetables and flowers offers one of the better solutions to overcome the problem. However, a number of schemes have been implemented by the state in cooperation with the center like State Horticulture Mission Scheme, Schemes of National Horticulture Board, etc. to promote the protected cultivation in the state. The polyhouse cultivation of vegetables and flowers in Almora and Dehradun districts, respectively, is a very profitable enterprise. The polyhouse cultivation prevalent in the region ranged from very low-cost wood-based polyhouses of size $100 \mathrm{~m}^{2}$ to a high-cost GI framed polyhouses of $10,000 \mathrm{~m}^{2}$ in size. However, there are some limitations of the study such; for example, (i) it is based on a medium sample size (number of farmers who practice protected cultivation); (ii) the extent of coverage was low, as small geographical regions were covered; and (iii) there were time and resource constraints in carrying out the project.

\section{The Policy Implications Emerging from the Study Are as Follows}

Polyhouse cultivation of vegetables and flowers in the region needs to be further promoted on a larger scale. However, the profitability of polyhouse cultivation under risk due to climatic events like heavy storm is reduced. However, it stills remains rewarding when taken up under a subsidy scheme. Hence, the policy on subsidy needs to be continued to encourage a large number of farmers to adopt the protected cultivation, which has already witnessed tremendous potential in the region and mitigates the risk involved in polyhouse cultivation. Further, the insurance agencies should be encouraged to insure the polyhouse structure against natural calamities. With regard to market development, flower mandi needs to be opened in the Dehradun region so that farmers get a better price for their produce in the nearest market. Start-ups or the agriclinic agencies should be founded in the region to provide advisory services to polyhouse cultivators of the region. Finally, the polyhouse cultivators should organize themselves and form farmer producer organizations so that they can better service themselves, be it the input delivery or the marketing of the produce. Several intentions will emerge from this study for future researche studies; viz., (i) a large number of samples can be selected with adequate time and resources, (ii) comparative evaluation studies can be taken up with the crops grown under polyhouses versus crops taken up in open field conditions and (iii) different economic tools/indicators may be used to assess such the techno-economic feasibility of such projects. 
Author Contributions: All authors contributed in preparation, analyses, writing, editing and approved the final version of the manuscript. All authors have read and agreed to the published version of the manuscript.

Funding: The research project was funded by the ICAR Extra Mural Project of Agricultural Extension Division. This research publication was financially supported by Vice Deanship of Research Chairs at King Saud University.

Institutional Review Board Statement: Not Apllicable.

Informed Consent Statement: Informed consent was obtained from all subjects involved in the study.

Data Availability Statement: The data presented in this study are openly available in the public domain given in the references.

Acknowledgments: The authors express gratitude to the financial support of Vice Deanship of Research Chairs at King Saud University and ICAR-Indian Agricultural Research Institute, New Delhi for providing necessary facilities and support.

Conflicts of Interest: The authors declare no conflict of interest.

\section{Appendix A}

Table A1. Crop yield in open field and protected cultivation in Uttarakhand.

\begin{tabular}{cccc}
\hline \multirow{2}{*}{ Vegetables } & \multicolumn{3}{c}{ Average Yield (Kg/ha) } \\
\cline { 2 - 4 } & Open & Polyhouse & \% Increase Over Open \\
\hline Tomato & 33,500 & 57,200 & 70.7 \\
\hline Capsicum & 7500 & 37,700 & 402.7 \\
\hline Cucumber & & 67,300 & 40 \\
\hline Cauliflower (sown in August) & 21,000 & 29,400 & 377.3 \\
\hline Garden pea (sown in August) & & 14,773 & 238.3 \\
\hline Tomato [20] & 11,000 & 52,500 & 582.2 \\
\hline Tomato [21] & 6000 & 20,300 & 112.2 \\
\hline Brinjal [21] & 4500 & 30,700 & 225.9 \\
\hline Cabbage [21] & 65,800 & 139,600 & 955 \\
\hline Cauliflower [21] & 38,500 & 125,500 & 282 \\
\hline Capsicum [21] & 2000 & 21,100 & 664.7 \\
\hline Beans [21] & 50,000 & 191,000 & 316.7 \\
\hline Pea [21] & 17,000 & 130,000 &
\end{tabular}

\section{References}

1. GoI. Agricultural Statistics at a Glance, 2019; Ministry of Agriculture and Farmers Welfare, Government of India: New Delhi, India, 2020.

2. GoUK. Uttarakhand Action Plan on Climate Change-Transforming Crisis into Opportunity; Government of Uttarakhand: Dehradun, India, 2014. Available online: http:/ / www.moef.gov.in/sites/default/files/Uttarakhand\%20SAPCC.pdf (accessed on 8 May 2018).

3. Annual Report 2011-2012; Vivekananda Parvatiya Krishi AnusandhanSansthan (VIPKAS): Almora, India, $2012 ;$ pp. $72-73$.

4. Bhatnagar, P.R. Strategies for Protected Cultivation for Small and Marginal Farmers in India. In Agriculture: Towards a New Paradigm of Sustainability; Excellent Publishing House: New Delhi, India, 2015; pp. 158-166. ISBN 978-93-83083-64-0. Available online: http:/ / www.krishisanskriti.org/vol_image/07Sep201505091128.pdf (accessed on 8 May 2018).

5. Singh, V.P.; Singh, P.K.; Bhatt, L.; Maurya, S.K.; Jeena, A.S. Low cost protected structures for enhancing productivity and livelihood security of farming community of Uttarakhand hills-An Overview. Progress. Res. 2013, 8, 155-159.

6. Annual Report, 2006-2007; Department of Agriculture and Education and Indian Council of Agricultural Research, Ministry of Agriculture: New Delhi, India, 2007; Available online: https:/ /icar.org.in/files/ar0607/11-Tribal-and-hill.pdf (accessed on 8 May 2018). 
7. Varkey, L.M.; Kumar, P. Price risk management and access to finance for rubber growers: The case of price stabilization fund in Kerala. Indian J. Agric. Econ. 2012, 66, 65-88.

8. Viswanatha Reddy, K.; Kumar, P. An Economic Appraisal of Mango Processing Plants of Chittoor District in Andhra Pradesh Indian J. Agric. Econ. 2010, 65, 277-297.

9. GOI. Horticulture Database-2010-11; National Horticulture Board, Ministry of Agriculture, GOI: New Delhi, India, 2010.

10. GOI. Horticulture Database-2014-15; National Horticulture Board, Ministry of Agriculture, GOI: New Delhi, India, 2014.

11. NHB (Various issues). In Indian Horticulture Database; National Horticulture Board, Ministry of Agriculture and Farmers Welfare, GoI: New Delhi, India, 2020.

12. Directorate of Horticulture and Food Processing; Government of Uttarakhand: Chaubatiya, India, 2017.

13. GoI. Horticulture Mission for North East and Himalayan States, Operational Guidelines-2010; GoI: New Delhi, India, 2010.

14. Mission for Integrated Development of Horticulture (MIDH); Ministry of Agriculture and Farmers Welfare; Government of India. Available online: http:/ / midh.gov.in (accessed on 12 July 2017).

15. Official Records of State Horticulture Department, Uttarakhand. Available online: https://shm.uk.gov.in/ (accessed on 15 July 2017).

16. Impact Evaluation of National Horticulture Mission (NHM) and Horticulture Mission for North East and Himalayan States (HMNEH). Available online: http:/ / midh.gov.in (accessed on 20 July 2017).

17. Available online: http://nhb.gov.in/nhb_beneficiaries.aspx (accessed on 20 July 2017).

18. Bishta, D.R.; Kumar, P.; Mathur, V.C. Progress and performance of kisan credit card scheme with a case study of Bihar. Agric. Econ. Res. Rev. 2012, 25, 125-135.

19. Prakash, P.; Kumar, P. Performance of kisan credit card scheme in Tamil Nadu. Indian J. Agric. Econ. 2016, 71, 191-211.

20. Jethi, R.; Srinivas, K.; Bisht, J.K. Economics of production of tomato under open and protected field conditions in hills of Uttarakhand. Indian J. Agric. Econ. 2012, 48, 13-16.

21. Negi, V.S.; Maikhuri, R.K.; Rawat, L.S.; Parshwan, D. Protected Cultivation as An Option of Livelihood in Mountain region of Central Himalaya, India. Int. J. Sustain. Dev. World Ecol. 2013, 20, 416-425. Available online: https://www.researchgate.net/ publication/263215235_Protected_cultivation_as_an_option_of_livelihood_in_mountain_region_of_central_Himalaya_India (accessed on 3 May 2018). [CrossRef] 